NBSIR 80-2079

\title{
An Economic Analysis of Efficiency Improvements to Residential Gas- and Oil-Fired Central Heating Equipment
}

\section{Stephen R. Petersen}

Building Economics and Regulatory Technology Division

George E. Kelly

Building Equipment Division

Center for Building Technology National Engineering Laboratory National Bureau of Standards U.S. Department of Commerce Washington, D.C. 20234

July 1980

\section{$-$}

10

.456

$80-2079$

1980

c.2

\section{Sponsored by}

The Department of Energy

Washington, D.C. 20461 



\section{AN ECONOMIC ANALYSIS OF EFFICIENCY IMPROVEMENTS TO RESIDENTIAL GAS- AND OIL-FIRED CENTRAL HEATING EQUIPMENT}

Stephen R. Petersen

Building Economics and Regulatory Technology Division

George E. Kelly

Building Equipment Division

Center for Building Technology National Engineering Laboratory National Bureau of Standards U.S. Department of Commerce Washington, D.C. 20234

July 1980

Sponsored by

The Department of Energy

Washington, D.C. 20461

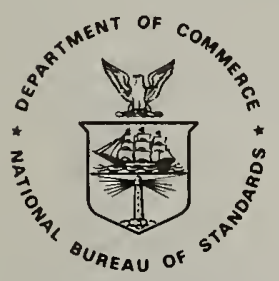

U.S. DEPARTMENT OF COMMERCE, Philip M. Klutznick, Secretary Luther H. Hodges, Jr., Deputy Secretary Jordan J. Baruch, Assistant Secretary for Productivity. Technology, and Innovation NATIONAL BUREAU OF STANDARDS, Ernest Ambler, Director 



\section{ABSTRACT}

Minimum performance standards for new residential gas- and oil-fired furnaces and bollers will be promulgated by the Department of Energy in the early $1980^{\prime} \mathrm{s}$. These standards will implicitly require that a number of design modifications be made to improve the seasonal efficiency of many basic furnace/boiler configurations. This report examines the potential improvement in seasonal efficiency due to a number of such modifications, as well as their life-cycle cost effectiveness. Included in the analysis are intermittent ignition devices (for gas-fired equipment), improved heat exchangers, stack dampers, external venting (with preheated air), and improved blower motor efficiencies (for forced-air furnaces). Simulated furnace performance data, the DoE/NBS furnace and boiler test procedures, recent estimates of modification costs, and a wide range of annual heating requirements and fuel costs are used in the analysis. The intermittent ignition device and improved blower motor were found to be cost effective on all gas-fired furnaces. The improved heat exchanger was cost effective for all new gas- and oil-fired equipment. The stack damper and external venting modifications were found to be cost effective for indoor equipment only in installations where substantial annual heating requirements are prevelant. Minimum efficiency criteria for new furnaces and boilers are developed, based on the estimated performance of current configurations representative of lower efficiency models, upgraded with those energy-saving modifications which are generally cost effective and can be implemented without serious disruption in the industry. 
The work in this report has been conducted as an interdisciplinary research project by the Building Economics and Regulatory Technology Division and the Building Equipment Division within the Center for Bullding Technology, National Engineering Laboratory, at the National Bureau of Standards. This effort has been supported by the Consumer Product Efficiency Branch in the Office of Buildings and Community Systems, at the U.S. Department of Energy.

The methodology outlined in this report employs a parametric analysis technique. The numerical values resulting from this analysis are valid only for the set of parameters specified. The NBS analysis and selection of parameters covers only a few of the many factors that DoE is required by law to consider in setting minimum efficiency standards. 


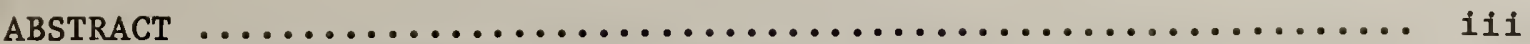

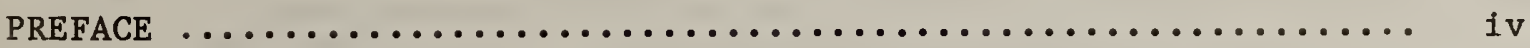

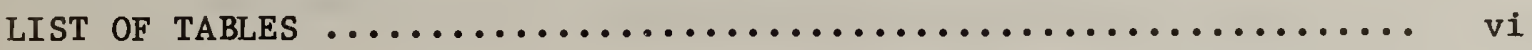

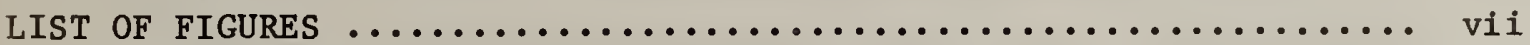

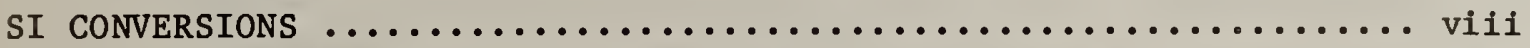

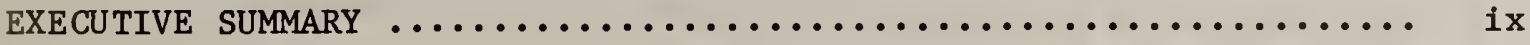

1. INTRODUCTION $\ldots \ldots \ldots \ldots \ldots \ldots \ldots \ldots \ldots \ldots \ldots \ldots \ldots \ldots \ldots \ldots \ldots \ldots \ldots . \ldots \ldots$

2. NEED FOR ECONOMIC ANALYSIS IN MINIMUM STANDARDS

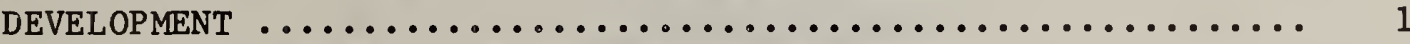

3. EQUIPMENT DESIGN MODIFICATIONS AND CORRESPONDING

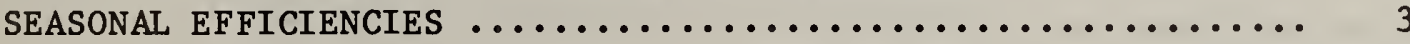

3.1 Modifications Considered ....................... 3

3.2 Estimating Improvements in Seasonal Efficiency Due to

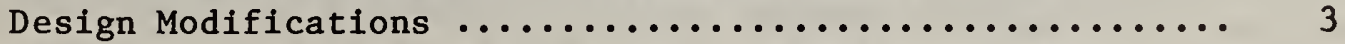

3.3 Estimating the Relative Cost Effectiveness of Design

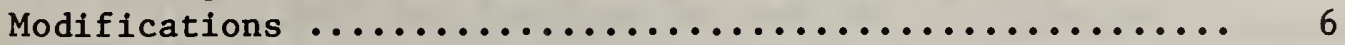

4. CALCULATION OF ANNUAL ENERGY SAVINGS AND LIFE-CYCLE COSTS $\ldots \ldots 10$

4.1 Calculating Annual Energy Requirements and Annual Energy

Costs for a Furnace or Boiler .................... 10

4.2 Estimating Annual Heating Requirements and Design

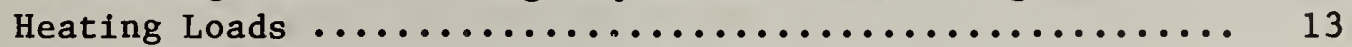

4.3 Calculation of Annual Energy Savings ................ 1

4.4 Life-Cycle Cost Analysis of Design Modifications ........ 21

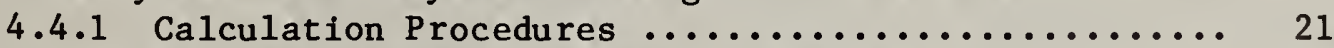

4.4.2 Economic Assumptions Used in Analysis ........... 22

4.4.3 Results of Life-Cycle Cost Analysis ............. 23

4.4.4 Implications for Outdoor Furnaces and Boilers ..... 28

5. IMPLICATIONS FOR STANDARDS DEVELOPMENT ................. 29

5.1 An Economically Optimal Standard for Consumers .......... 29

5.2 A Practical Standard for Manufacturers ................ 29

5.3 Other Considerations in Setting Standards for Furnaces

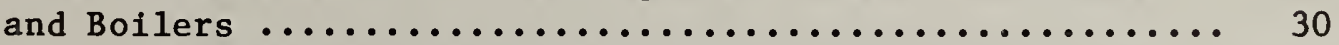

5.4 Technical Basis for Standards Setting ............... 33

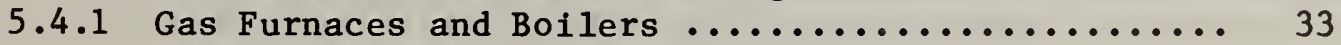

5.4 .2 0il Furnaces and Boilers .................. 34

6. AN ALTERNATIVE METHOD FOR SPECIFYING MINIMUM BLOWER MOTOR

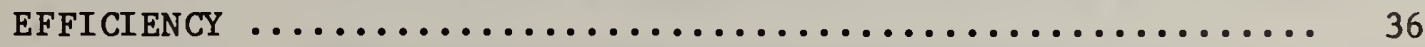

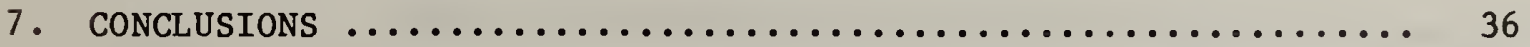




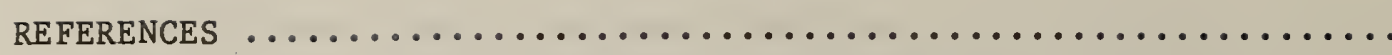

APPENDIX A. Derivation of Modified Uniform Present

Worth Factors ........................... $A-1$

APPENDIX B. Explanation of Design Modifications to

Furnace/Boilers ...

\section{LIST OF TABLES}

1. Design Modifications to Improve the Performance of New Gas-

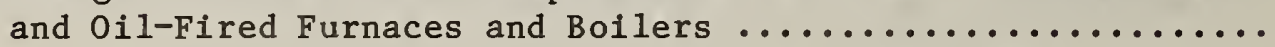

2. Seasonal Efficiency of Selected Gas-Fired Furnace/Boiler

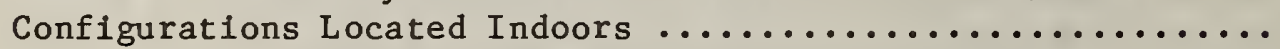

3. Seasonal Efficiency of Selected 011-Fired Furnace/Boiler

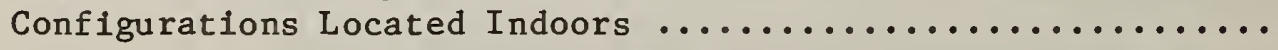

4. Relative Savings-Cost Ratios for Selected Modifications to Gas-Fired Furnaces/Boilers Located Indoors

5. Relative Savings-Cost Ratios for Selected Modifications to

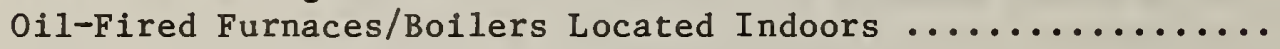

6. Annual Heating Hours Calculated for $1200 \mathrm{sq}$. ft. House in

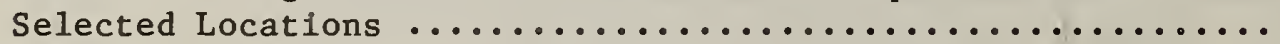

7. Annual Heating Requirements, Design Heating Loads and Annual

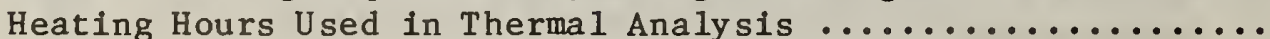

8. Annual Energy Savings by Modification for a Gas Furnace with

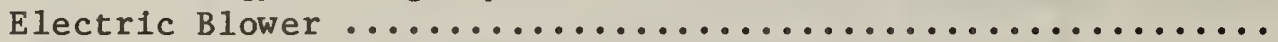

9. Annual Energy Savings by Modification for an Oil Furnace with

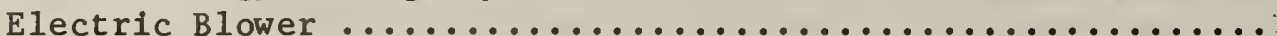

10. Minimum Annual Heating Requirements (in million Btu) for Cost-Effective Modifications, Gas Furnace ................

11. Minimum Annual Heating Requirements (in miliion Btu) for Cost-Effective Modifications, $0 i 1$ Furnace ...............

12. Furnace/Boiler Output Capacities Corresponding to Annual

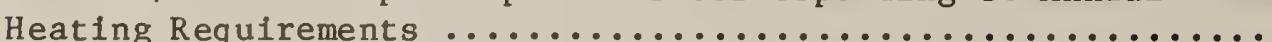




\section{LIST OF TABLES (continued)}

Page

13. Minimum Seasonal Efficiencies for Gas-Fired Central Heating

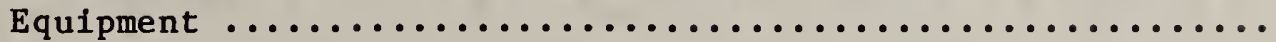

14. Minimum Seasonal Efficiencies for 0il-Fired Central Heating

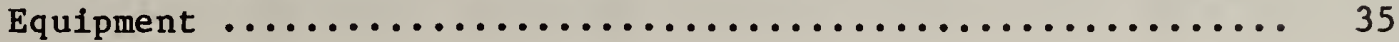

15. Minimum Efficiencies for Furnace Blower Motors .......... 36

\section{LIST OF FIGURES}

1. Annual Heating Requirements as a Function of Design Heating Loads (1200 sq. ft. house) ....................... 15

2. Relationship Between Design Heating Load and Corresponding Minimum Annual Heating Requirements ................... 16

3. Typical P.S.C. and S.P. Motor Efficiencies and Suggested Minimum Motor Efficiency Level 


\section{SI CONVERSIONS}

Because the energy analysis in this report is based directly on the Department of Energy Test Procedure for Furnaces and Boilers and is directly supportive to the DoE effort to develop minimum performance standards for furnaces and boilers, compatable customary units of measurement are used. Since the United States is a signatory to the Eleventh General Conference on Weights and Measures, which defined and gave official status to the Metric SI system, the following conversion factors are provided to assist users of SI units.

$\begin{array}{ll}\text { Energy: } & 1 \mathrm{Btu}=1.055 \times 10^{3} \text { joule } \\ \text { Power: } & 1 \mathrm{Btu}=0.293 \text { watt } \\ & 1 \mathrm{hp}=0.7450 \mathrm{~kW} \\ \text { Temperature: } & 1^{\circ} \mathrm{F}=9 / 5^{\circ} \mathrm{C}+32 \\ \text { Length: } & 1 \mathrm{foot}=0.3048 \text { meter }\end{array}$




\section{EXECUTIVE SUMMARY}

This report provides a microeconomic analysis of selected design modifications to residential furnaces and bollers in order to generate benchmark data for the development of minimum performance standards for new furnaces and boilers by the Department of Energy. These minimum performance standards will pertain to residential gas and oil-fired forced warm-air furnaces with heat input rates less than $225,000 \mathrm{Btu}$ per hour $(\mathrm{Btu} / \mathrm{h})$ and residential gasand oil-fired, hot water and steam boilers with heat input rates less than 300,000 Btu per hour.

A number of design modifications to improve the seasonal energy efficiency of new furnaces and boilers are examined in this report. These include:

- automatic stack damper,

- intermittent ignition device,

- direct venting with preheated air,

- improved heat exchanger, and

- high efficiency blower motor.

Detailed calculations of annual energy savings attributable to each of these modifications are made. Life-cycle dollar savings are then calculated for each modification and compared with corresponding costs in order to determine the cost effectiveness to the end user. Other factors relevant to the deve1opment of minimum performance standards are also examined, including the acceptable performance of the modification considered and their potential for large-scale disruption to the producing industries.

A useful furnace life of twenty years and a real discount rate (i.e., after adjusting for inflation) of four percent were used in a life-cycle cost analysis of the modifications. Base year energy costs of $\$ 0.30$ per therm for natural gas, $\$ 1.00$ per gallon for fuel oil, and $\$ 0.04$ per $\mathrm{kWh}$ for electricity were also used, with a sensitivity analysis performed to examine the effects of this factor on the cost effectiveness of the modifications examined. Energy and dollar savings were calculated for annual heating requirements (AHR) of a house ranging from five to eighty million Btu. Except for the intermittent ignition device, which appears to be cost effective in nearly all cases, the savings attributable to the modifications considered are approximately proportional to AHR. Thus, while some of the modifications are not cost effective in relatively small or tightly insulated houses in the milder climates (e.g., stack damper and direct venting with preheated air), they are all likely to be cost effective in larger houses in the colder climates. Since the furnace/boiler size is likely to be larger in houses with larger AHR than in those with relatively small AHR, this report suggests that a minimum efficiency standard would require a higher level of efficiency for a larger furnace/boiler than for a smaller sized unit.

Two important constraints are identified that tend to reduce potential minimum efficiency requirements below levels that are shown to be cost effective in this report: 
(1) stack dampers on oil-fired furnaces and boilers have been associated with odor problems, and

(2) the requirement that all new furnaces include direct venting with preheated air would place a severe redesigning burden on the industry.

In addition, the improved blower motor efficiency for furnaces, which is shown to be cost effective for gas furnaces only, cannot be factored into the minimum seasonal efficiency requirements directly. Thus the blower motor efficiency level must be specified independently of the fuelutilization efficiency if higher motor efficiencies are to be required.

Based on the economic analysis and constraints identified in this report, the following seasonal efficiencies appear to be a reasonable starting point for developing minimum efficiency standards for new furnaces and boilers:

Heating Equipment Type

$\underline{\text { Gas }}$

011

Indoor furnaces and

indoor boilers with

output capacities

$<40,000 \mathrm{Btu} / \mathrm{h}$

$60 \%$

$76 \%$

Indoor furnaces and

indoor boilers with

output capacities

$\geq 40,000 \mathrm{Btu} / \mathrm{h}$

$74 \%$

$76 \%$

Outdoor furnaces and

outdoor bollers 


\section{INTRODUCTION}

This report provides a microeconomic analysis of selected design modifications to residential furnaces and boilers in order to generate benchmark data for the development of minimum performance standards for new furnaces and boilers by the Department of Energy. These minimum performance standards will pertain to residential gas and oil-fired forced warm-air furnaces with heat input rates less than 225,000 Btu per hour and residential gas- and oilfired, hot water and steam boilers with heat input rates less than 300,000 Btu per hour.

The development of minimum performance standards is required by the National Energy Act of 1978 and is the responsibility of the Department of Energy (DoE). The National Bureau of Standards (NBS) has been requested by the Department of Energy to assist in this endeavor by providing a technical and economic analysis of the various design options likely to be cost effective for residential furnaces and boilers. This report summarizes the economic analysis pertaining to this NBS effort and provides both a methodology and data relevant to the development of such minimum performance standards.

A number of design modifications to improve the seasonal energy efficiency of new furnaces and boilers are examined in this report. Detailed calculations of annual energy savings attributable to each modification are made, based on the DoE furnace/boiler test procedures [5] developed at NBS. Life-cycle do1lar savings are then calculated for each modification and compared with corresponding costs in order to determine the cost effectiveness to the end user. Other factors relevant to the development of minimum performance standards are also examined, including the acceptable performance of the modifications considered and their potential for large-scale disruption to the producing industries.

This report does not reflect a position for or against the promulgation of minimum furnace and boiler standards. Rather, given that such standards are legislatively mandated, the purpose is to promote the development of minimum standards that can be realistically implemented and which are economically justified.

\section{NEED FOR ECONOMIC ANALYSIS IN MINIMUM STANDARDS DEVELOPMENT}

Several major criteria have been established by the Department of Energy for consideration in the development of minimum performance standards for furnaces and boilers [4]. These have been interpreted to provide the following constraints on the minimum standards development process:

1. The standards must be stated in terms of a minimum acceptable level of seasonal efficiency, as demonstrated by the DoE test procedure [5],

2. The standards must be technically feasible, 
3. The standards must be achievable without a major disruption of the industries manufacturing the appliances,

4. The standards must not be set at a level which will force unsafe, unreliable or unacceptable products on the consumer, and

5. The standards must be capable of being met with product and design changes which are "cost effective."

It is this last criterion that is most subjective and which has many interpretations. Should the design changes resulting from the minimum standard be cost effective everywhere in the country or just for average installation conditions in the country? Should there be different minimum standards for different geographical regions? For different heating requirements? For different energy prices? One way to answer these questions is through an economic analysis which evaluates the design changes in terms of their impact on life-cycle costs, over a wide range of applications. If such an analysis is made a part of the minimum standards development process, it has the additional benefit of encouraging standards which are consistent with existing economic incentives and thus are likely to be implemented with a minimum of enforcement costs.

The type of minimum performance standard that is most likely to be promulgated by $\mathrm{DoE}$ is a single standard imposed at the point of manufacture. This is because residential furnaces and boilers are manufactured at a central location, often sold through distributors or retailers, and usually not subjected to major modification at the installation site. Such a single standard, however, is basically inconsistent with the concept of economic efficiency. That is, a single standard is likely to require too much investment in energy efficiency in installations with low annual heating costs and too little investment in energy efficiency in installations with relatively high heating costs. A more flexible standard which requires a level of energy efficiency that varies with annual heating requirements and energy prices would save more energy dollars for the same total investment cost, or the same level of energy dollars at a lower total investment cost. Such an alternative standard would also be more consistent with existing economic incentives to install more efficient heating equipment in colder climates, in larger buildings, or where higher fuel prices prevail.

Because the single-standard approach has been favored by DoE, however, the scope of this report is limited to an analysis of a single standard imposed at the point of manufacture and not differentiated by geographic region. As a result, it is assumed that the major purpose of such a standard would be to eliminate production models which fail to achieve the minimum level of energy efficiency which can be economically justified in most, if not all installations in the United States. Alternative mechanisms, including market forces (e.g., fuel costs), information programs (e.g., appliance labeling), and tax credits, would provide incentives to exceed such a level, where economically justified. For this reason, the thrust of this report will be to identify the design options for several furnaces and boilers that can be shown to be cost effective in most conventional installations on a life-cycle basis. 
3. EQUIPMENT DESIGN MODIFICATIONS AND CORRESPONDING SEASONAL EFFICIENCIES

\subsection{MODIFICATIONS CONSIDERED}

A number of modifications can be incorporated into the design of fossil-fuelburning heating equipment in order to improve seasonal energy utilization efficiency. Modifications which are either presently available or likely to be available in the very near future are listed in table 1 , together with their additional purchase cost to the consumer in 1980 dollars, as estimated by Booz, Allen, and Hamilton [1]. A short description of each of these modifications is presented in Appendix B.

All but one of the modifications listed in table 1 improve the seasonal fossil-fuel utilization efficiency of the heating equipment. The high efficiency blower motor does not affect fossil-fuel utilization efficiency but does decrease the amount of electricity needed to operate the system. Fossil-fuel utilization and electricity utilization are kept separate in order to reflect the significantly different prices of these two energy types. Dollar valuations of the two energy types are added together in order to arrive at a total operating cost. Except when referring specifically to blower motor efficiency, the term "efficiency" or "seasonal efficiency" will refer to fossil fuel utilization efficiency.

Power burners for gas-fired systems and fuel/air modulation modifications for both gas- and oil-fired systems were eliminated from the economic analysis for the following reasons. While a power burner is standard on oilburning equipment, the use of a stack damper on a gas-fired unit provides most of the same benefits in reducing off-period flue losses, costs roughly the same as a power burner, uses significantly less electrical energy, and has the important advantage of not requiring a major redesign of a furnace or boiler. The fuel/air modulation modification has the highest first cost of all the modifications considered and provides little increase in seasonal efficiency once a vent damper and intermittent ignition device (IID) are installed to reduce off-cycle losses.

\subsection{ESTIMATING IMPROVEMENTS IN SEASONAL EFFICIENCY DUE TO DESIGN MODIFICATIONS}

Annual energy usage and energy savings due to improvements in heating equipment design are a function of seasonal efficiency rather than a steady-state efficiency. Although the improvements in seasonal efficiency associated with many of the modifications in table 1 have been estimated in a number of reports $[1,3,10]$, an (unpublished) in-house NBS study, using the NBS computer model DEPAF, Design and Performance Analysis of Furnaces [3], appears to provide the most complete and internally consistent analysis of furnace and boiler design options. This study was performed for the Department of Energy for the purpose of setting efficiency targets. It involves the analysis of furnace/boiler performance in several geographic locations and covers all of the design options (and many of their combinations) listed in table 1.

Table 2 summarizes the results of this NBS study for a high efficiency gasfired furnace or boiler, having a steady-state efficiency of 77 percent, in 
Table 1. Design Modifications to Improve the Performance of New Gasand Oil-fired Furnaces and Boilers

\begin{tabular}{|c|c|c|c|c|}
\hline \multirow[b]{2}{*}{ Symbol } & \multirow[b]{2}{*}{ Design Option } & \multicolumn{2}{|c|}{ Application ${ }^{a}$} & \multirow[b]{2}{*}{$\begin{array}{l}\text { Approximate } \\
\text { Cost }(1980)^{b}\end{array}$} \\
\hline & & Oil & Gas & \\
\hline $\mathrm{P}$ & Power Burner & $\mathrm{s}$ & $\mathrm{x}$ & $\$ 120$ \\
\hline $\mathrm{F}$ & Fuel and Air Modulation & $\mathrm{X}$ & $\mathrm{X}$ & 150 \\
\hline$S$ & Automatic Stack Damper & $\mathrm{x}$ & $x$ & 125 \\
\hline I & Intermittent Ignition Device (IID) & $\mathrm{s}$ & $\mathrm{X}$ & 75 \\
\hline $\mathrm{vX}$ & Direct Venting with Preheated Air & $\mathrm{X}$ & $\mathrm{X}$ & 85 \\
\hline $\mathrm{E}$ & $\begin{array}{l}\text { Improved Heat Exchanger } \\
\text { ( } 5 \text { percentage points } \\
\text { improvement in } \eta_{\text {ss }} \text { ) }\end{array}$ & $\mathrm{X}$ & $\mathrm{X}$ & 25 \\
\hline B & $\begin{array}{l}\text { High Efficiency Blower Motor } \\
\text { (P.S.C.d instead of Shaded Pole) }\end{array}$ & $\mathrm{x}$ & $\mathrm{X}$ & 10 \\
\hline
\end{tabular}

a $\mathrm{S}=$ standard equipment.

$X=$ design option either presently available or likely to be available shortly.

b Source: Booz, Allen \& Hamilton, Inc., Energy Efficiency Program for Appliances, Furnaces, Home Heating Equipment, Humidifiers, Oct. 1977 [1].

c $n_{s s}=$ steady-state efficiency of furnace or boiler, based on DoE test procedures [5].

d P.S.C. = permanent-split capacitor. 


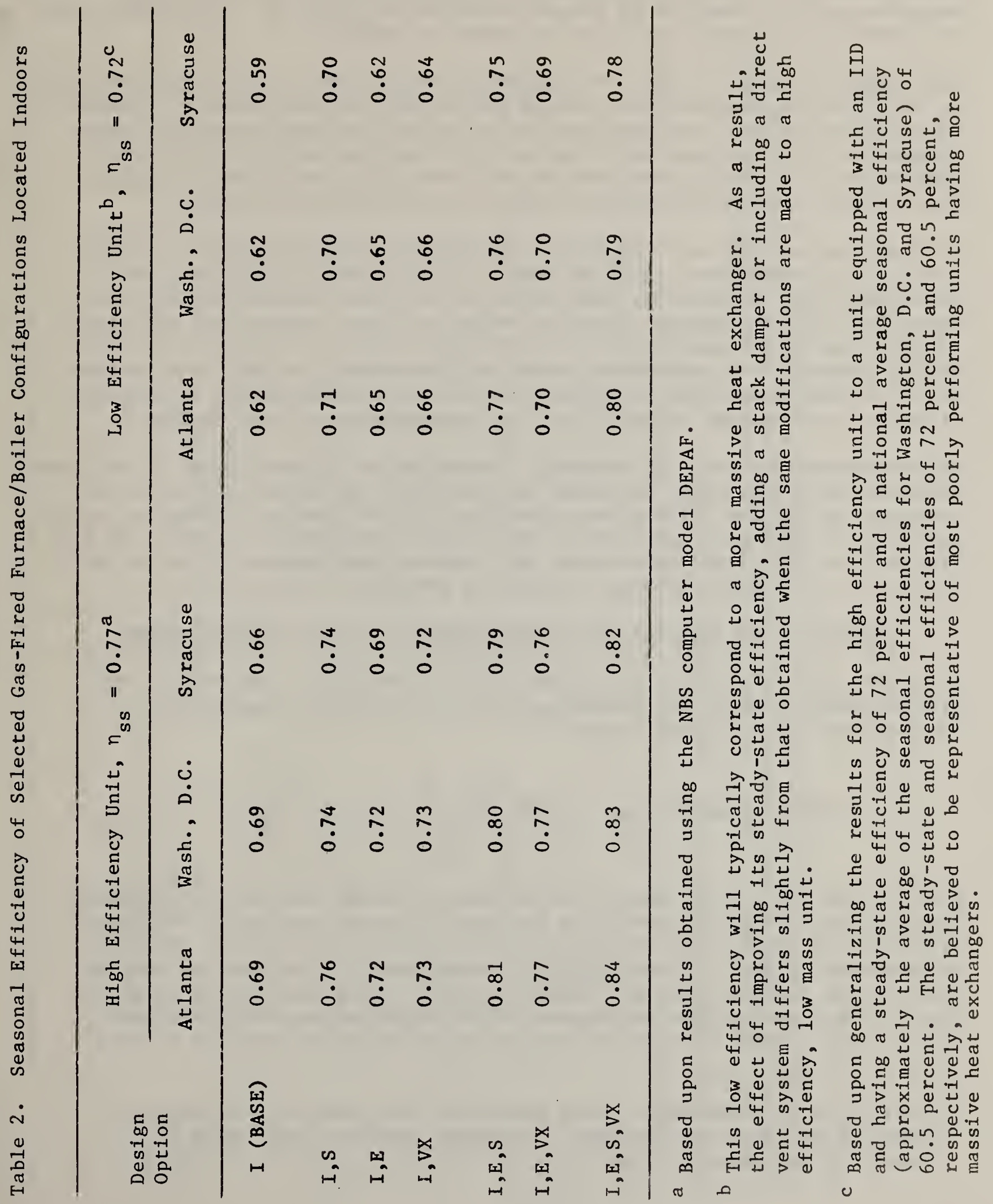


three geographic locations and for the design options of interest. Similarly, DEPAF results for a high efficiency oil-fired furnace or boiler with a steady-state efficiency of 83 percent are shown in table 3 . The symbols used to identify each design variation are shown in table 1.

Also shown in tables 2 and 3 are estimated seasonal efficiencies for gas- and oil-fired units, respectively, having steady-state efficiencies of 72 percent. These latter numbers were generated by adjusting the DEPAF computer results downward to give seasonal efficiencies which are representative of poorer performing units having more massive heat exchangers, while maintaining the same relative seasonal efficiency trends for the different regions.

It should be pointed out that in all the design options presented in tables 2 and 3 , an intermittent ignition device (I) is assumed to be installed. This simplified approach was used since the economic analysis in this report shows that the intermittent ignition device is almost always cost effective, either alone or in combination with other modifications. Since we are primarily interested in incremental costs and incremental savings (see section 4 ), it is more meaningful to present the various design options as modifications to units already equipped with an intermittent ignition device.

This procedure provides an internally consistent set of data which is in close agreement with the little data that are available on seasonal efficiencies predicted by the DoE furnace test procedure [5] for some of the simple design options. It also provides a set of data that is believed to bracket, on the high and low side, the steady-state and seasonal performance of the majority of gas- and oil-fired furnaces and boilers presently being marketed.

\subsection{ESTIMATING THE RELATIVE COST EFFECTIVENESS OF DESIGN MODIFICATIONS}

Using the seasonal efficiency data in tables 2 and 3 , the percentage reduction in annual fossil-fuel requirements due to the design modifications examined can be calculated using:

$$
\text { Percent Fuel Savings }=(100) \frac{\frac{1}{\eta_{1}}-\frac{1}{n_{2}}}{\frac{1}{n_{1}}}=(100) \frac{n_{2}-n_{1}}{\eta_{2}} \text {, }
$$

where $\eta_{1}$ and $\eta_{2}$ are the seasonal efficiencies without and with the modification, respectively. The resulting savings (in percentage terms) can then be divided by the cost of the modification (from table 1) to obtain relative savings-cost ratios. " These relative savings-cost ratios show the percent reduction in heating costs per dollar invested. They can be used to determine the most cost-effective order in which modifications should be made. Tables 4 and 5 list the relative savings-cost ratios for selected combina-

* Implicit in this analysis is the assumption that each of the modifications has the same service life. Different service lives would require an adjustment to cost. 


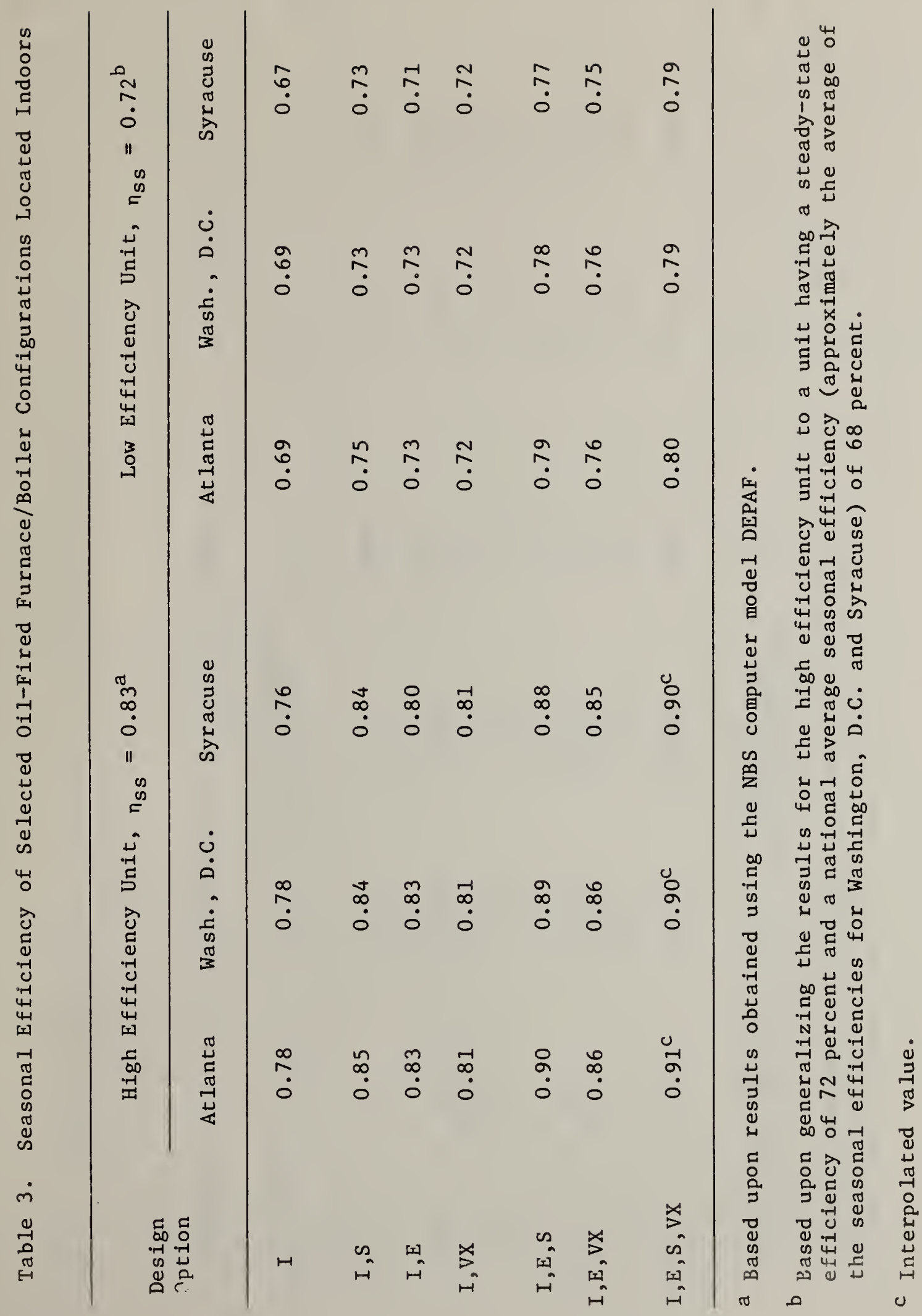




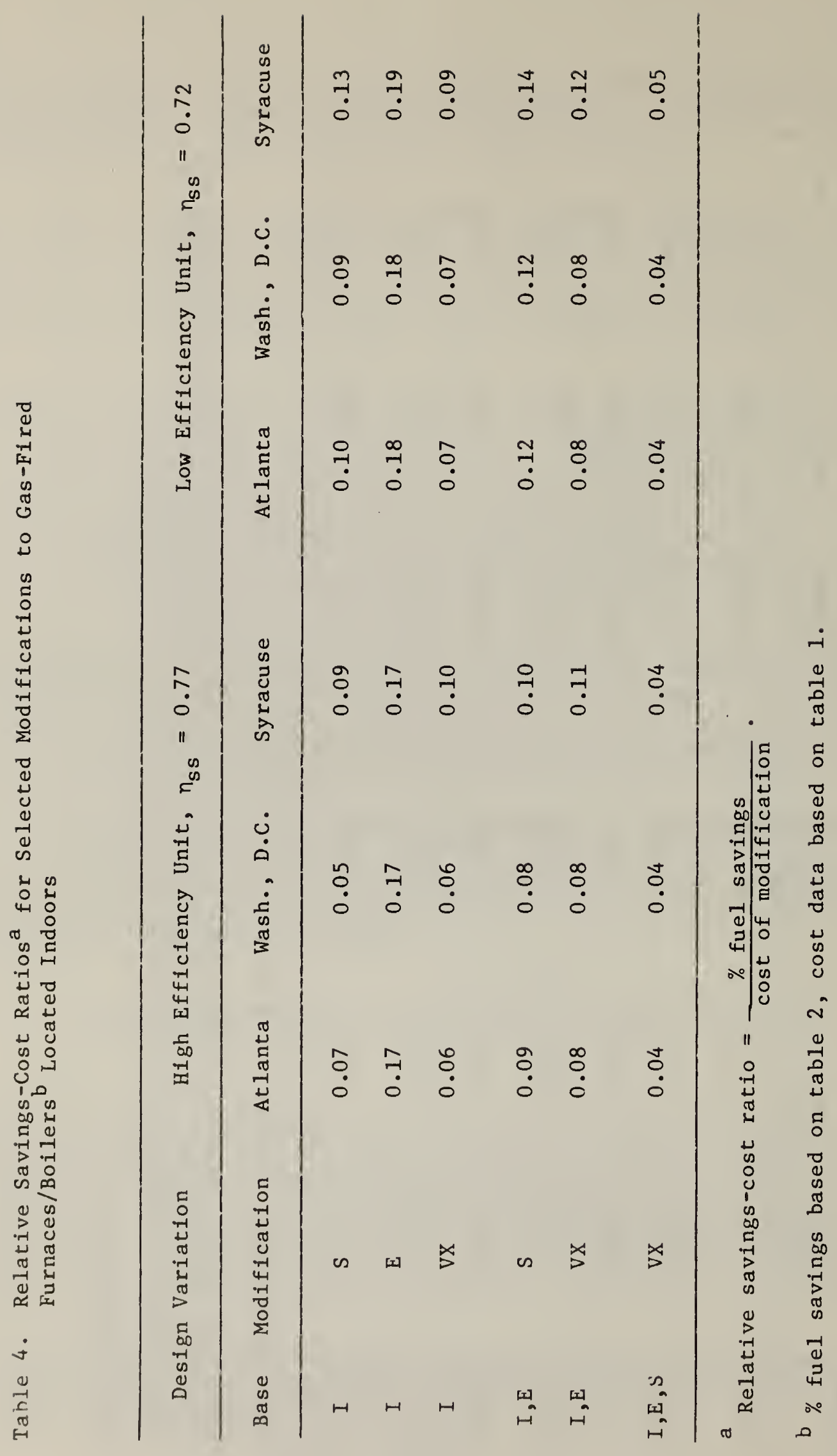




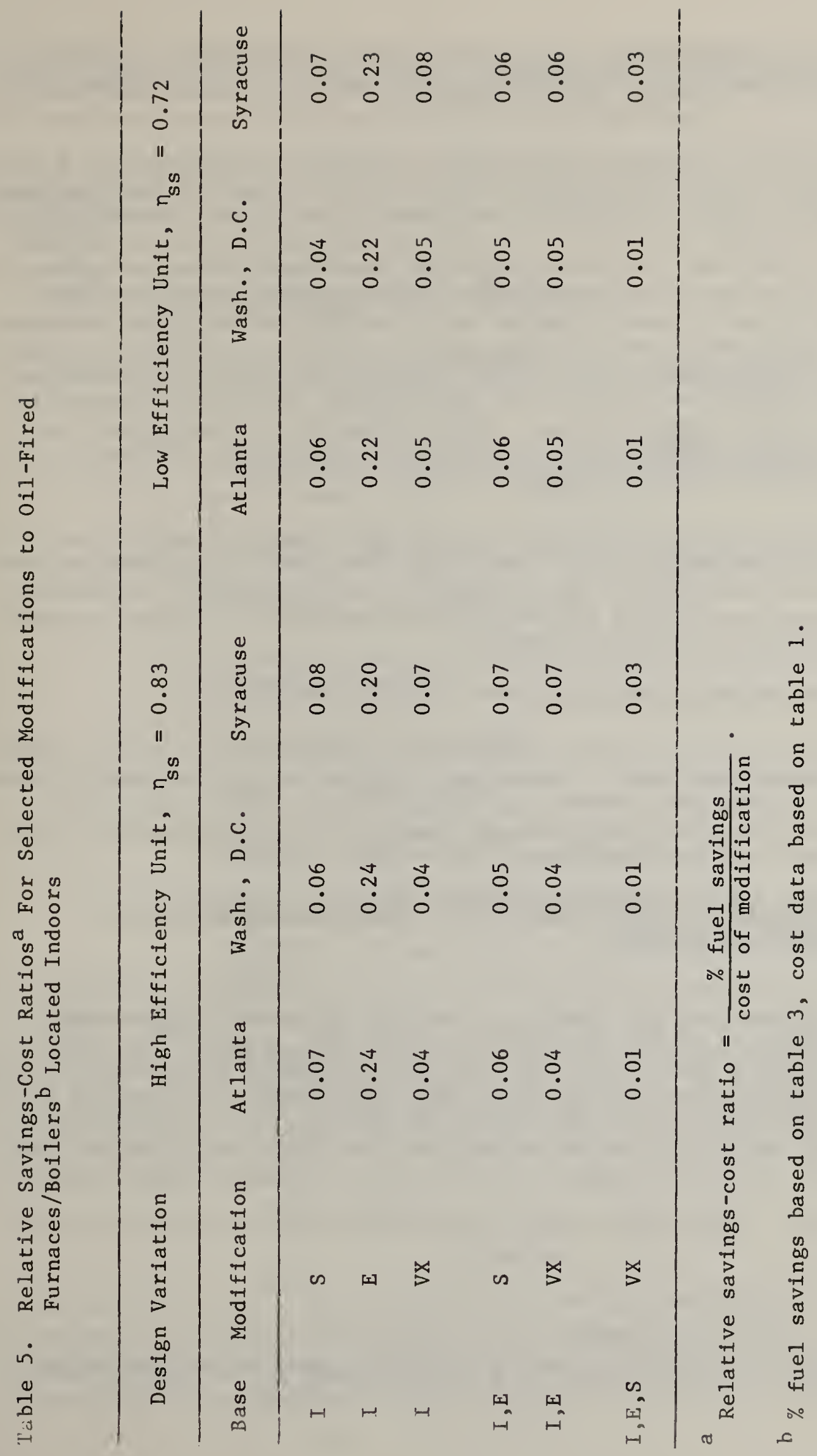


tions of the stack damper ( $S$ ), the improved heat exchanger $(E)$ and direct venting (with preheating of incoming air, VX), for gas- and oil-fired units, respectively.

From tables 4 and 5 it is easily seen that the single modification to a gasor oil-fired unit which is most cost effective is the improved heat exchanger (E). This modification is therefore considered first in the determination of life-cycle savings in section 4. Once this modification has been made, tables 4 and 5 show that the stack damper ( $S$ ) is slightly more cost effective than direct venting with preheating (VX), except in the case of the highefficiency gas-fired furnace or boiler in the coldest of the three locations (Syracuse). Based upon these results, and our belief that with mass production and design improvements the cost of the stack damper will decrease more rapidly than a direct vent system, the stack damper is evaluated second in the economic analysis which follows. This leaves direct venting with preheating of incoming combustion air as the last modification of these three to be considered for implementation.

Given the relative cost effectiveness of the stack damper, improved heat exchanger and direct venting with preheating, the absolute cost effectiveness of these modifications can now be calculated. This requires an estimate of the actual energy savings and a life-cycle cost valuation of those savings. This is the subject of the next section.

\section{CALCULATION OF ANNUAL ENERGY SAVINGS AND LIFE-CYCLE COSTS}

This section covers four topics: computation procedures to determine annual energy requirements and costs of operating a furnace or boiler; specification of the annual heating requirements and design heating loads used in the analysis; life-cycle cost procedures and assumptions; and discussion of the results obtained from the engineering and economic analyses.

\subsection{CALCULATING ANNUAL ENERGY REQUIREMENTS AND ANNUAL ENERGY COSTS} FOR A FURNACE OR BOILER

The Department of Energy has published testing and calculation procedures for determining the seasonal performance of residential central furnaces and boilers [5], based on an NBS research report for this purpose [9]. These procedures provide a methodology for computing the number of burner operating hours ( $\mathrm{BOH}$ ) and the annual energy costs (AEC) for a given size furnace in a given house and climate. This methodology is used in this report to calculate the annual energy and dollar savings for the design modifications examined. However, instead of using design heating requirements (DHR) ${ }^{\star}$ and heat-

* The design heating requirement is the heating requirement to be met by the furnace or boiler in Btu per hour at the 97-1/2 percent outdoor design temperature. 
ing load hours (HLH) * to determine the annual heating requirements (AHR) of different structures, as in the recommended test procedure, the annual heating requirements are specified directly in the analysis.

Based on the DoE/NBS test procedure, the annual number of burner operating hours (BOH) for a furnace or boller may be calculated using the following equation:

$$
\mathrm{BOH}=\frac{\mathrm{AHR}-(\mathrm{AHH})\left(Q_{p}\right)\left(n_{u}\right)}{(3413)(\mathrm{PE}+\mathrm{yBE})+\left(Q_{i n}-Q_{p}\right)\left(n_{u}\right)}
$$

where $A H R=$ the annual heating requirement, in $\mathrm{Btu}$, of the residence in which the furnace or boiler is to be installed,

$\mathrm{AHH}=$ annual heating hours (i.e., the number of hours in wich the outdoor dry-bulb temperature falls below the balance point temperature of the house),

$Q_{\text {in }}=$ fuel input rate to the furnace or boiler in $B t u / h$,

$Q_{p}=$ fuel input rate to the pilot in $B t u / h$,

$\eta_{u}=a$ fraction representing the seasonal efficiency of the furnace or boiler,

$3413=$ number of Btu in one $\mathrm{kWh}$,

$\mathrm{PE}=$ power to burner $(\mathrm{kW})$,

$\mathrm{BE}=$ power to furnace blower $* *(\mathrm{~kW})$, and

$y=$ ratio of average blower on-time to average burner on-time (assumed to be 1.38 for furnace, 1.0 for boiler or furnace employing a single motor to drive a power burner and blower).

Equation 4-1 accounts for the useful output from the pilot flame during heating hours and credits the unit with the heat output from the electric blower and/or power burner when the equipment is operating. In the economic analysis which follows, it is assumed that the fuel input rate to the pilot on gas-fired units is $1000 \mathrm{Btu} / \mathrm{h}$ and that the blower employed uses a one-third

* Heating load hours $=\frac{24 \times \text { Heating Degree Days (base } 65^{\circ} \mathrm{F} \text { ) }}{\Delta \mathrm{T} \text { design }}$, where $\Delta \mathrm{T}_{\text {design }}=65^{\circ} \mathrm{F}-(97-1 / 2$ percent outdoor design temperature $)$.

The energy used by the pump motor on a hot water boiler is small and is neglected in the analysis which follows. 
horsepower motor. The blower design option consists of using a permanentsplit capacitor (P.S.C.) motor with an efficiency of 65 percent instead of a shaded pole (S.P.) motor with an efficiency of 45 percent.

For the purposes of this report the output capacity $\left(Q_{i n} \times \eta_{s s}\right)$ of the furnace/boiler is assumed to be 1.7 times the design heating load, where $\eta_{s s}$ is the steady-state efficiency of the furnace or boiler. That is, the furace or boiler is assumed to be 70 percent oversized. Oversizing of this magnitude is consistent with the need to provide a reasonably short warm-up period after a thermostat setback. This is also the oversizing ratio used in the furnace and boiler test procedures recommended by NBS and DoE.

Annual fuel consumption (AFC) and annual electricity consumption (AELC) can then be calculated using:

$$
\begin{aligned}
\mathrm{AFC} & =\frac{(\mathrm{BOH})\left(\mathrm{Q}_{\text {in }}-\mathrm{Q}_{\mathrm{p}}\right)+(8760)\left(\mathrm{Q}_{\mathrm{p}}\right)}{\mathrm{Btu} / \text { unit } F} \text {, and } \\
\mathrm{AELC} & =(\mathrm{BOH})(\mathrm{PE}+\mathrm{yBE})
\end{aligned}
$$

where $8760=$ the number of hours in a year, and

$$
\begin{aligned}
\mathrm{Btu} / \mathrm{unit} & \mathrm{F}_{\mathrm{F}}= \\
& \text { the energy content in Btu per unit of fuel purchased } \\
& (\mathrm{e} . \mathrm{g} \cdot, \text { gallon, therm). }
\end{aligned}
$$

The annual energy cost (AEC) is then:

$$
A E C=(A F C)\left(\$ / \text { unit }_{F}\right)+(A E L C)(\$ / k W h),
$$

where $\$ /$ unit $\mathrm{F}=$ the price in dollars of a unit of fuel, and

$$
\$ / \mathrm{kWh}=\text { the price in dollars of a } \mathrm{kWh} \text {. }
$$

It is interesting to note that for a given furnace or boiler, an increase in fuel utilization efficiency will reduce both fuel requirements and electricity requirements. Replacement of the pilot light will reduce annual fuel requirements but increase $\mathrm{BOH}$ and thus increase annual electricity use by the furnace blower and power burner (if any).* Conversely, improvement in the furnace blower motor or power burner will reduce electricity requirements but increase fuel requirements. When neither a pilot light nor auxiliary electrical equipment exist, $\mathrm{BOH}$ and $\mathrm{AFC}$ are directly proportional to AHR.

Another important fact is that the energy savings due to the IID are inversely related to annual heating hours (AHH). That is, a greater number of AHH

* Note that the energy savings from the IID may be larger than calculated by the above methodology if the standing pilot flame contributes to the air conditioning load. However, this is ignored in the present study because of the difficulty in generalizing this effect. 
results in a shorter non-heating season, lower standby losses from the pilot and, as a result, smaller savings from an intermittent ignition device. In addition, the absolute value of the pilot losses are approximately constant for a given value of $A H H$ and $Q_{p}$. Thus any estimate of a seasonal fuel utilization efficiency which includes pilot losses changes as the annual heating requirement (AHR) changes. This is part of the reason that the seasonal efficiencies presented in tables 2 and 3 were only given for units equipped with intermittent ignition devices.

In order to evaluate the change in energy requirements due to the IID, the number of annual heating hours must be estimated for the actual building in which the furnace/boiler is to be installed. AHH are, however, not only a function of climate, but a function of the balance point temperature of the building as well. Recent NBS analysis of a $1200 \mathrm{sq}$. ft. house sequentially modified to reduce heat losses [12] has shown that AHH vary significantly with the thermal integrity of the shell. Table 6 provides the AHH for this $1200 \mathrm{sq}$. $\mathrm{ft}$. house for several levels of thermal integrity and corresponding balance points in 14 locations. The AHH corresponding to the approximate level of insulation that is economically optimal in each location (as determined in [12] for fossil-fuel heating systems) are denoted by asterisks.

\subsection{ESTIMATING ANNUAL HEATING REQUIREMENTS AND DESIGN HEATING LOADS}

In order to calculate annual fuel and electricity consumption of a furnace or boiler using equations 4-1 through 4-3, some estimate of annual heating requirements (AHR) is needed. Figure 1 provides quantitative data on AHR for smaller single-family houses in the U.S. based on a recent NBS study [12]. The lines for each of the thirteen cities represented show the range of AHR for the same basic $1200 \mathrm{sq}$. ft. single-story house with insulation levels varying from nil (top end) to extreme by today's standards (bottom end). The same lines also show the corresponding design heating loads for the identical house configuration. This data is based on an hour-by-hour analysis using test reference year (TRY) weather data [14], with thermostat settings at $68^{\circ} \mathrm{F}$ during the day and $60^{\circ} \mathrm{F}$ at night. In general, the AHR for an appropriately insulated $1200 \mathrm{sq}$. ft. house will be approximately one-third of the maximum value shown (i.e., $1 / 3$ of the AHR for the uninsulated house). According to this data, AHR lower than five million Btu would appear reasonable only in the mildest regions of the U.S. In houses with less than $1200 \mathrm{sq}$. ft., moderately well insulated and conservatively operated. A larger house or one operated less conservatively would have higher AHR.

Estimates of design heating loads (DHL) are also needed in order to determine the proper furnace or boiler size for a given installation. (Output capacity is assumed to be sized 1.7 times the DHL.) The data in figure 1 show that there is a poor correlation between the design heating load (DHL) and annual heating requirements as different locations are considered. For example, in Phoenix, a DHL of $30,000 \mathrm{Btu} / \mathrm{h}$ corresponds to AHR of approximately 18 million Btu, while in Seattle the same DHL corresponds to AHR of over 60 million Btu.

However, minimum AHR corresponding to DHL's at different levels can be established that will prove useful. Figure 2 provides a single curve, based on 
Table 6. Annual Heating Hours (AHH) Calculated for $1200 \mathrm{sq}$. ft. House in Selected Locations ${ }^{a}$

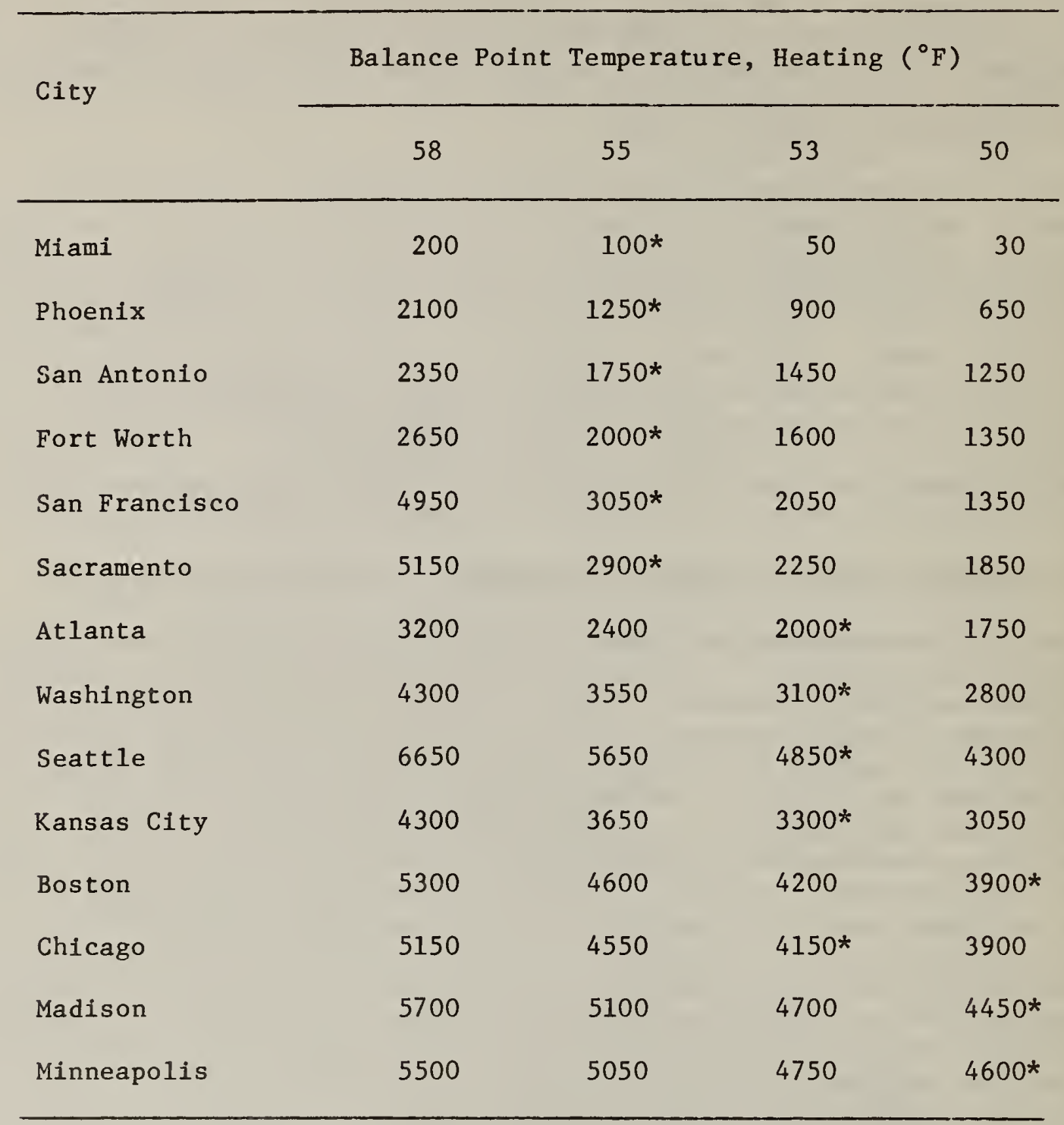

a Source, table 6.9 in [12].

* Approximate balance point corresponding to economic level of insulation for fossil-fuel heating system (based on $1200 \mathrm{sq}$. ft. house). 


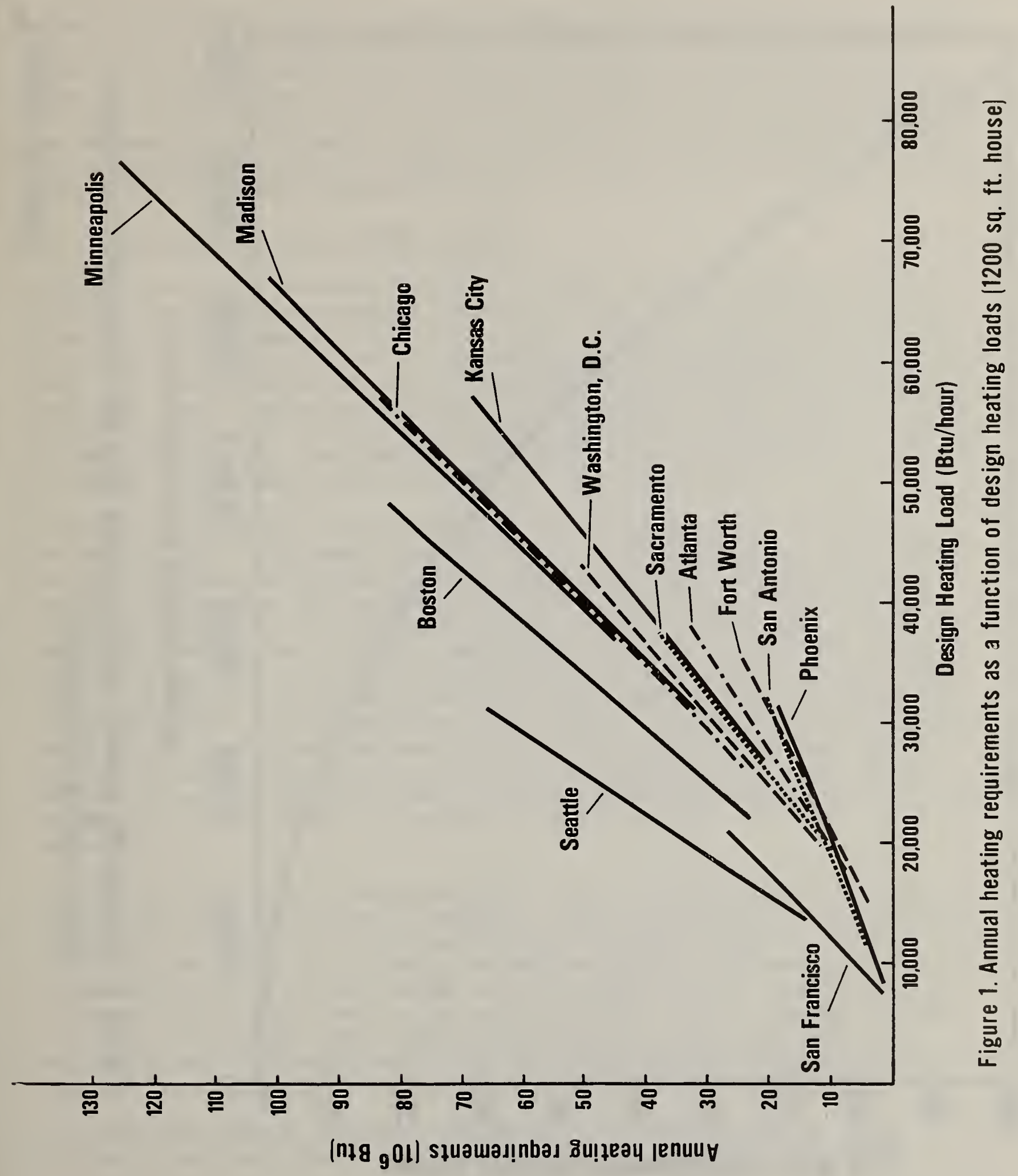




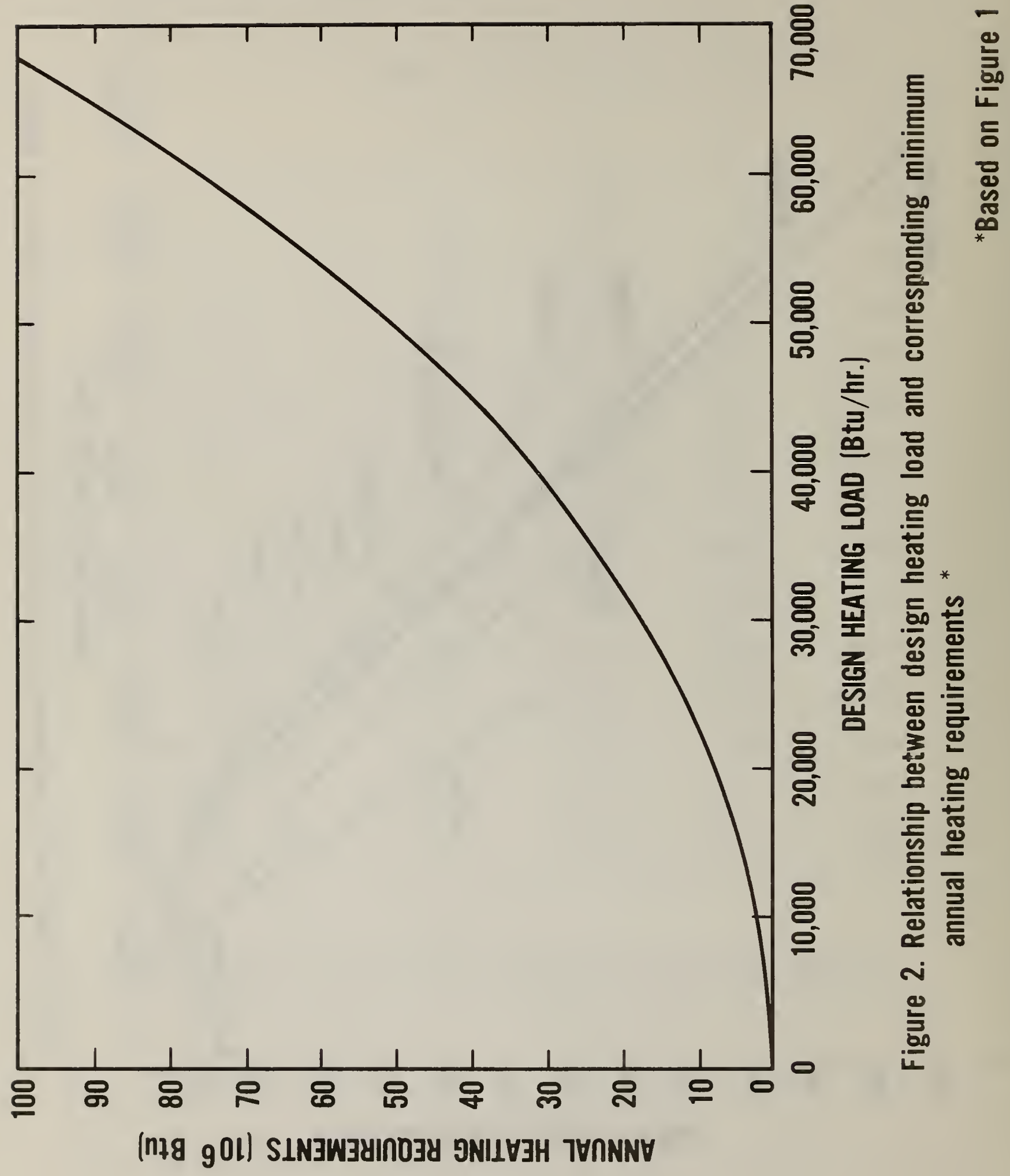


figure 1, which shows the approximate minimum AHR for any given value of DHL. This curve is used to generate the DHL corresponding to the range of AHR ( 5 to 80 million Btu) examined in the following subsection. It will also be of some use in developing data for establishing minimum performance standards for furnaces and boilers since the minimum AHR corresponding to any given furnace/ boiler size can be estimated. Table 7 provides the design heating loads and annual heating hours that are assumed to correspond to each level of AHR examined in the range of 5 to 80 million Btu.

\subsection{CALCULATION OF ANNUAL ENERGY SAVINGS}

Tables 8 and 9 show the annual savings in fossil fuel and electricity estimated for the design improvements examined in this report, using the calculation methodology shown in section 4.1. Fossil fuel savings are shown in gallons $(140,000 \mathrm{Btu} / \mathrm{gallon})$ for oil and therms $(100,000 \mathrm{Btu} /$ therm) for natural gas. For the intermittent ignition device (IID, gas-fired furnaces and boilers on $1 y$ ) the energy savings are calculated as a function of 2500,3500 , and 5000 annual heating hours. Calculation of savings for the IID are shown in part I of table 8 . For all other modifications, savings are calculated as a function of annual heating requirements (AHR) of 10,20,40 and 80 million Btu.

Calculations of savings from improvements in blower efficiency assume an increase in motor efficiency from 45 to 65 percent. Calculations of savings for the improved heat exchanger, stack damper, and direct venting (with preheat) are based on the seasonal efficiency data shown in tables 2 and 3 for Washington, D.C. This location was selected for the analysis because the percentage savings are the most conservative of the three locations, and thus provide an estimate of minimum savings to be expected. Energy savings shown in part II of table 8 and part I of table 9 were calculated in the sequential order shown, with the IID installed in all cases. (The sequential ordering is based on diminishing savings-cost ratios.) Thus these calculations provide the incremental savings from each additional modification as shown. Energy savings in part III of table 8 and part II of table 9 were calculated for each modification independently, although the IID is assumed to be used in all cases.

Note that the savings in electricity due to the improved blower efficiency require that more fossil fuel be burned in order to provide an equivalent Btu output. (The "waste" heat from the blower is actually useful in terms of overall furnace output.) As a result, the improved blower efficiency will be advantageous only if the Btu output from the fossil fuel is less costly (on a life-cycle cost basis) than the Btu output from the blower. Because natural gas prices are significantly lower than heating oil prices (per Btu) the improved blower efficiency modification is ranked higher in the sequential analysis for the gas-fired systems than for the oil-fired systems.

This data base will be used for calculating the life-cycle savings from furnace/boiler design modifications in the following sections. 
Table 7. Annual Heating Requirements, Design Heating Loads and Annual Heating Hours Used in Thermal Analysis

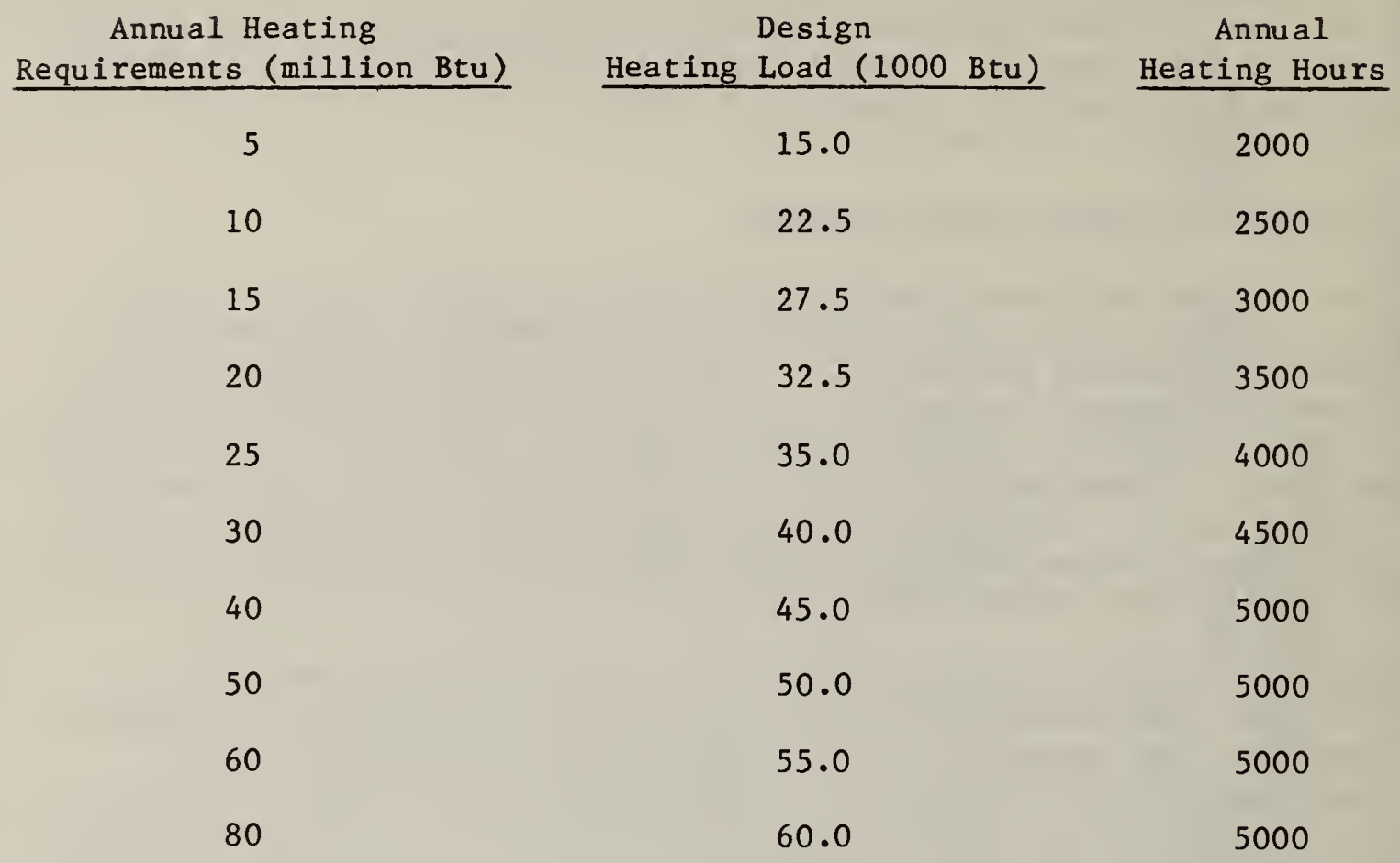


Table 8. Annual Energy Savings by Modification for a Gas Furnace with Electric Blower

I. Intermittent Ignition Device (IID)

\begin{tabular}{l} 
Furnace Efficiency \\
Steady \\
State (before modification) \\
\hline
\end{tabular}

$\begin{array}{ll}72 \% & 62 \% \\ 77 \% & 69 \%\end{array}$

II. Sequential Analysis ${ }^{b}$

$$
\text { A. } n_{\mathrm{ss}}=72 \%
$$

Improved Blower $(n=65 \%)$ Improved Heat Exchanger ( $5 \%$ ) Stack Damper

Direct Vent. (w/preheat)

B. $n_{\text {ss }}=77 \%$

Improved Blower $(n=65 \%)$ Improved Heat Exchanger ( $5 \%)$ Stack Damper

Direct Vent. (w/preheat)

$$
\text { Annual Gas (Electricity) Savings in Therms (kWh) }
$$

Annual Heating Hours

(Annual Heating Requirements ${ }^{a}$, million $\mathrm{Btu}$ )

\begin{tabular}{llll}
\hline 2500 & 3500 & 5000 & 5000 \\
$(10)$ & $(20)$ & $(40)$ & $(80)$ \\
\hline
\end{tabular}

$64.3(-30.0) \quad 54.2(-29.6) \quad 39.2(-28.1) \quad 38.8(-21.6)$ $64.2(-32.4) \quad 54.2(-31.9) \quad 39.1(-30.2) \quad 38.8(-23.4)$
Annual Gas (Electricity) Savings in Therms (kWh)

Annual Heating Requirements (million Btu)

\begin{tabular}{rrrrrrrr}
\hline & 10 & \multicolumn{2}{c}{20} & \multicolumn{1}{c}{40} & \multicolumn{1}{c}{80} \\
\hline-3.4 & $(62.5)$ & -5.0 & $(90.0)$ & -6.6 & $(120.7)$ & -11.2 & $(203.0)$ \\
6.7 & $(6.7)$ & 13.9 & $(9.5)$ & 28.4 & $(12.7)$ & 57.2 & $(21.3)$ \\
20.3 & $(20.1)$ & 41.7 & $(28.7)$ & 85.3 & $(38.1)$ & 171.9 & $(64.0)$ \\
4.6 & $(4.6)$ & 9.4 & $(0.5)$ & 19.2 & $(8.6)$ & 38.7 & $(14.4)$
\end{tabular}

$\begin{array}{lllllll}-3.0 & (60.4) & -4.3 & (86.8) & -5.8(116.0) & -9.7(196.0)\end{array}$

$\begin{array}{llllllll}5.5 & (5.8) & 11.3 & (8.3) & 23.1 & (11.0) & 46.5 & (18.5)\end{array}$

$\begin{array}{lllllllll}12.7 & (13.4) & 26.0 & (19.1) & 53.2 & (25.4) & 107.2 & (42.7)\end{array}$

$\begin{array}{llllllll}4.1 & (4.4) \quad 8.5 & (6.3) & 17.4 & (8.3) & 35.0 & (13.9)\end{array}$

III. Independent Analysis ${ }^{b}$

A. $n_{\mathrm{ss}}=72 \%$

Improved Blower $(n=65 \%)$

Improved Heat Exchanger (5\%)

Stack Damper

Direct Vent. (w/preheat)

$\begin{array}{rrrrrrrr}-3.4 & (62.5) & -5.0 & (90.0) & -6.6 & (120.7) & -11.2 & (203.0) \\ 6.7 & (6.7) & 13.9 & (9.5) & 28.4 & (12.7) & 57.2 & (21.3) \\ 16.7 & (16.6) & 34.4 & (23.6) & 70.4 & (31.5) & 141.9 & (52.8) \\ 8.8 & (8.8) & 18.2 & (12.5) & 37.3 & (16.7) & 75.2 & (28.0)\end{array}$

B. $n_{\text {ss }}=77 \%$

Improved Blower $(n=65 \%)$

$\begin{array}{lllllll}-3.0 & (60.4) & -4.3 & (86.8) & -5.8(116.0) & -9.7(196.0)\end{array}$

Improved Heat Exchanger (5\%)

Stack Damper

Direct Vent. (w/preheat)

$\begin{array}{llllll}5.5 & (5.8) & 11.3 & (8.3) & 23.1 & (11.0)\end{array}$

$46.5(18.5)$

$\begin{array}{llllllll}8.9 & (9.4) & 18.3 & (13.4) & 37.4 & (17.9) & 75.4(300.0)\end{array}$

$\begin{array}{llllllllll}7.2 & (7.6) & 14.8 & (10.9) & 30.4 & (14.5) & 61.2 & (24.4)\end{array}$

\footnotetext{
a AHR correspond to values given in table 7 for indicated annual heating hours.

b IID assumed to be used in all cases.
} 
Table 9. Annual Energy Savings by Modification for an Oil Furnace with Electric Blower

I. Sequential Analysis

Annual 0il (Electricity) Savings in Gallons (kWh)

Annual Heating Requirements (million Btu)

\begin{tabular}{lll}
\hline 10 & 20 & 40 \\
\hline
\end{tabular}

A. $n_{S S}=72 \%$

Improved Heat Exchanger

Stack Damper

Direct Vent. (w/preheat)

Improved Blower $(n=65 \%)$

B. $\eta_{\mathrm{ss}}=83 \%$

Improved Heat Exchanger

Stack Damper

Direct Vent. (w/preheat)

Improved Blower $(n=65 \%)$

II. Independent Analysis

A. $\eta_{\text {ss }}=72 \%$

Improved Heat Exchanger

Stack Damper

Direct Vent. ( $w /$ preheat)

Improved Blower $(\eta=65 \%)$

B. $n_{\mathrm{ss}}=83 \%$

Improved Heat Exchanger

Stack Damper

Direct Vent. (w/preheat)

Improved Blower $(\eta=65 \%)$

III. Modified Sequential Analysis

(No Stack Damper)

A. $n_{\text {ss }}=72 \%$

Improved Heat Exchanger

Direct Vent. (w/preheat)

Improved Blower ( $n=65 \%)$

B. $\eta_{S S}=83 \%$

LiI! $r$, ved Heat Exchanger

Direct Vent. (w/preheat)

Improved Blower ( $n=65 \%$ )

\begin{tabular}{|c|c|c|c|c|c|c|}
\hline $5.0(10.0$ & 10.3 & $(14.4)$ & 21.3 & $(19.3)$ & 43.1 & $(32.5)$ \\
\hline$(11.1)$ & 11.5 & $(16.0)$ & 23.7 & $(21.4)$ & 47.8 & $(36.0)$ \\
\hline & 2.1 & & 4.4 & $(4.0)$ & 8.9 & $(6.7)$ \\
\hline $.6(50$ & -2.2 & $(72.0)$ & -3.0 & $(96.0)$ & -5.0 & $(161.0)$ \\
\hline
\end{tabular}

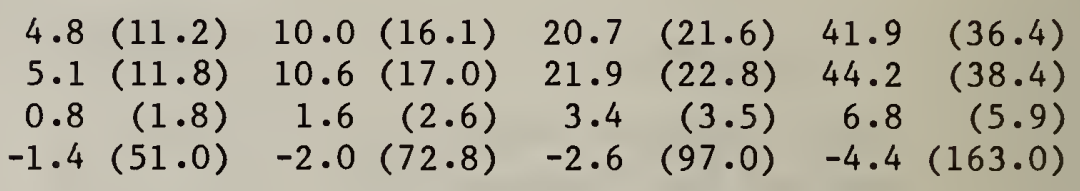

$\begin{array}{rrrrrrrr}4.8 & (11.2) & 10.0 & (16.1) & 20.7 & (21.6) & 41.9 & (36.4) \\ 5.7 & (13.2) & 11.9 & (19.1) & 24.6 & (25.6) & 49.7 & (43.1) \\ 3.0 & (6.8) & 6.2 & (9.9) & 12.7 & (13.3) & 25.7 & (22.3) \\ -1.8 & (57.9) & -2.6 & (83.1) & -3.5 & (111.0) & -5.8 & (187.0)\end{array}$

$$
\begin{array}{rrrrrrrr}
4.8 & (11.2) & 10.0 & (16.1) & 20.7 & (21.6) & 41.9 & (36.4) \\
2.6 & (6.1) & 5.5 & (8.8) & 11.3 & (11.6) & 22.9 & (19.8) \\
-1.5 & (53.1) & -2.2 & (76.0) & -2.9 & (101.0) & -4.8 & (170.0) \\
20 & & & & & & &
\end{array}
$$




\subsection{LIFE-CYCLE COST ANALYSIS OF DESIGN MODIFICATIONS}

\subsubsection{Calculation Procedures}

Once the reduction in annual fuel and electricity consumption has been determined, the savings in annual energy costs (AS) due to a given design modification can be calculated as

$$
A S=\left(A F C_{1}-A F C_{2}\right)\left(\$ / u_{i n t}\right)+\left(A E L C_{1}-A_{F L C}\right)(\$ / k W h),
$$

where $\mathrm{AFC}_{1}$ and $\mathrm{AELC}_{1}=$ annual fuel and electricity consumption, respectively, before the modification is installed, and

$\mathrm{AFC}_{2}$ and $\mathrm{AELC}_{2}=$ annual fuel and electricity consumption, respectively, after the modification is installed.

However, in order to compare such savings with the additional costs of the design modifications, they must be adjusted to equivalent savings in total life-cycle operating costs.

Life-cycle cost analysis is the most appropriate method of evaluating energy conserving design modifications because all relevant savings and costs incurred over the life of the modifications are considered on a time-equivalent basis. Time equivalency can be most readily performed by discounting all future savings (less maintenance and repair costs, if any) to the start of the useful life of the modifications. These adjusted savings, referred to as "present-value" life-cycle savings, can then be directly compared with the additional cost of the design modifications in order to determine the cost effectiveness of the modifications.

While the physical savings from design modifications are assumed to be constant from year to year, the dollar value of those savings is expected to increase over time because of rising energy prices. A modified version of a uniform present worth factor (UPW) is needed to relate the discounted value of the increasing dollar savings over the life of a modification to its annual dollar savings evaluated at the beginning of the first year of use. This modified UPW factor is designated as UPW* to to distinguish it from the more commonly used UPW factor which does not incorporate increasing dollar savings over time. The derivation of the UPW will be discussed in Appendix A.

In this report both the savings in fuel costs and electricity costs are considered in the life-cycle analysis. Total life-cycle savings (TS), in initial year dollars, are estimated using

$$
\begin{aligned}
\mathrm{TS} & =\left(\mathrm{AFC}_{1}-\mathrm{AFC}_{2}\right)\left(\$ / \mathrm{unit}_{\mathrm{F}}\right)\left(\mathrm{UPW}_{\mathrm{F}}^{*}\right) \\
& +\left(\mathrm{AELC}_{1}-\mathrm{AELC}_{2}\right)(\$ / \mathrm{kWh})\left(\mathrm{UPW}_{\mathrm{E}}^{*}\right)
\end{aligned}
$$

WLire $U P W_{F}^{*}$ and $U P W_{E}^{*}=$ the modiffed uniform present worth factors for the heating fuel and electricity, respectively. (UPW $_{\mathrm{F}}^{*}$ and $U P W_{E}^{*}$ will differ if the expected rate of price increase for fuel and electricity differs.) 
Any increase in maintenance-related costs due to a design modification must also be evaluated in present-value terms and added to its initial cost in order to better estimate the total cost (TC) for that modification. Thus

$$
\mathrm{TC}=\mathrm{IC}+\sum_{i=1}^{\mathrm{n}} \mathrm{MC}_{\mathrm{i}} /(1+\mathrm{D})^{\mathrm{y}_{\mathrm{i}}}
$$

where IC = initial cost

$\mathrm{n}=$ expected number of maintenance-related occurences over the life of the modification,

$M C_{i}=$ expected cost of the $i^{\text {th }}$ occurence (base year equals 1 ),

$y_{i}=$ year of the $i^{\text {th }}$ occurence, and

$D=$ discount rate .

If all savings and costs have been properly evaluated, each modification with present-value life-cycle savings greater than or equal to its total cost is considered to be cost effective. Conversely, modifications with savings less than costs are not considered to be cost effective.

\subsubsection{Economic Assumptions Used in Analysis}

In order to perform a life-cycle cost analysis, appropriate technical performance data and economic data must be selected. The technical performance data for the gas- and oil-fired furnaces and boilers have already been discussed (tables 2 and 3). A 20-year furnace life is assumed, based on the data presented by Booz, Allen and Hamilton [1], which in turn was based on a survey conducted of manufacturer representatives, distributors, and heating contractors. In that report it is assumed that the modifications considered have equally long lives. Cost data for the modifications are shown in table 1 (projected 1980 dollars), again as estimated by Booz, Allen and Hamilton. Increased maintenance costs above basic furnace maintenance costs are assumed to be negligible.* (If significant maintenance costs were to be anticipated, they could be directly incorporated into the analysis by adding them, discounted to 1980 dollars, to the initial costs as illustrated in equation 4-7).

In order to value the annual energy saving in 1980 dollars, 1979 DoE price projections** of 1980 prices [13] were used for gas and electricity, while

* Experience with both the intermittent ignition device and stack damper indicates that there have been increased maintenance costs associated with these modifications. It is assumed that newer designs will be more reliable and therefore need less maintenance. However, at the time of this writing, no actual projections of maintenance costs are available.

The "Trendlong" economic scenario was used, which assumes a moderate level of economic growth between 1980-2000. 
1979 Bureau of Labor statistics (BLS) data [2] were used as the basis for estimating 1980 fuel oil prices. (0il price data were taken from BLS because they better reflected the very significant increase in fuel oil during the year 1979.) In order to better estimate the minimum dollar savings that would occur due to the installation of a given modification, energy prices in the mildest heating climates in the continental U.S. were examined, $1 . e$. the south and southwest. Then the lowest regional price for each energy type among these regions was used. Price projections for all three energy types through the year 2000 are based on the implicit price increase (in real terms) projected in the DoE report [13]. As a result of this procedure, the following prices and projected real price increases were used:

$\begin{array}{lccc}\begin{array}{c}\text { Energy } \\ \text { Type }\end{array} & \begin{array}{c}\text { Lowest Price } \\ \text { Region }\end{array} & \begin{array}{c}1980 \\ \text { Price }\end{array} & \begin{array}{c}\text { Average Rate of Price } \\ \text { Increase Through 2000 (real) }\end{array} \\ \text { Gas } & \text { Southwest } & \$ 0.30 / \text { therm } & 3.4 \% \\ \text { Oil } & \text { South } & \$ 1.00 / \text { gallon } & 3.2 \% \\ \text { Electricity } & \text { South } & \$ 0.04 / \mathrm{kWh} & 0.8 \%\end{array}$

In order to develop modified uniform present worth factors (UPW*) for each energy type, a "real" (i.e., after adjustment for inflation) discount rate of four percent is used in this report. This is approximately equivalent to the ten percent nominal discount rate (with six percent inflation assumed) used in similar NBS analyses of air conditioners and insulation in residential applications. A four percent real discount rate for homeowners implies that a minimum after-tax, after-inflation annual rate of return on investment of four percent will be realized from all investments that are cost effective. However, this rate of return may be considerably higher for investments with present-value savings significantly larger than costs.

Based on a 20-year life, a four percent discount rate, and the long-term real energy price escalation rates shown above, the following modified uniform present worth factors were derived, as explained in Appendix A:

$\begin{array}{ll}\text { Energy Type } & \frac{\mathrm{UPW}^{*}}{18.8} \\ \text { Gas } & 18.5 \\ 011 & 14.6\end{array}$

\subsubsection{Results of Life-Cycle Cost Analysis}

A series of economic analyses was performed on the design modifications examined in this report in order to determine the combination of energy price and hsatirg requirements which make each modification cost effective on a life- 
cycle basis. Energy savings data are based directly on tables 8 and 9 . Modification costs are from table 1 . A range of prices was examined for natural gas $(\$ 0.20$ to $\$ 0.40 /$ therm) and oil ( $\$ 0.80$ to $\$ 1.20 /$ gallon), with the midpoint equivalent to the estimated 1980 energy prices discussed in section 4.4.2. Electricity costs were held constant at $\$ 0.04 / \mathrm{kWh}$ in all cases. However, this is of little consequence except in the analysis of improved blower efficiency. Note that the rate of price escalation for each energy type (and thus the modified uniform present worth factors, UPW*) does not vary with changes in base price assumptions, but remains constant as shown in section 4.4 .2 .

The cost effectiveness of the IID for a gas-fired furnace or hoiler is a function of annul heating hours (AHH) rather than annual heating requirements. Specifically, the savings are directly proportional to ( 8760

hrs/yr minus AHH). Thus the fewer AHH, the more likely the IID is to be cost effective. Based on the energy savings shown in table 8 and the $\$ 75$ cost in table 1 , the IID appears to be cost effective over the entire range of energy prices and annual heating hours examined. Even at $\$ 0.20$ per therm and 5000 annual heating hours the life-cycle savings of $\$ 132$ exceed the first cost of the modification. As a result, the IID is assumed to be incorporated into the design of the gas furnace and boiler in all subsequent analyses of design modifications.* (Note that even with significant maintenance costs the IID is likely to be cost effective in the majority of applications.)

For all modifications except the intermittent ingition device (IID), the energy and dollar savings are most sensitive to the annual heating requirements (AHR). Tables 10 and 11 show the minimum AHR for which these modifications are cost effective, given the fuel prices shown, for gas and oil furnaces, respectively. That is, at the minimum AHR shown, the present-value life-cycle (20 years) savings just equal the first costs shown. At any AHR greater than those shown, the savings exceed costs. The design improvements shown in tables 10 and 11 are analyzed in two distinct ways, sequentially and independently.** The sequential analysis begins with the most costeffective modifications and examines the incremental effects of each additional modification in order of decreasing cost effectiveness. The general ordering of modifications is the same for gas and oil furnaces except that

* Present-value savings $=$ (savings in therms $)(\$ /$ therm $)\left(\right.$ UPW $\left._{\text {gas }}^{*}\right)$

$$
\begin{aligned}
& +(\text { savings in } \mathrm{kWh})(\$ / \mathrm{kWh})\left(\mathrm{UPW}_{\mathrm{kWh}}^{*}\right) \\
& =(38.8)(\$ 0.20)(18.8)+(-23.4)(\$ 0.04)(14.6)=\$ 132 .
\end{aligned}
$$

Savings in therms and $k W h$ are from table 8 , part $I$.

** In addition, table 11 , part III, shows a modified sequential analysis where the direct venting (with preheat) modification is examined directly after the improved heat exchanger, leaving out the stack damper. As will be discussed in section 5.3, odor problems with stack dampers on oilfired units may preclude requiring this latter modification on new units. 
Table 10. Minimum Annual Heating Requirements ${ }^{a}$ (in million Btu) for CostEffective Modifications ${ }^{b}$, Gas Furnace

Price Per Therm (Gas)

$\$ 0.20 \quad \$ 0.30 \quad \$ 0.40$

I. Sequential Analysis

A. $\eta_{\text {ss }}=72 \%$

Improved Blower Eff. (@ $\$ .04 / \mathrm{kWh}$ )

Improved Heat Exchanger

Stack Damper

Direct Vent. (w/preheat)

$\begin{array}{lll}3 & 5 & 7\end{array}$

$\begin{array}{lll}9 & 6 & 5\end{array}$

$15 \quad 10 \quad 8$

$45 \quad 30 \quad 23$

B. $\eta_{s s}=77 \%$

Improved Blower Eff. (@ $\$ .04 / \mathrm{kWh}$ )

Improved Heat Exchanger

Stack Damper

Direct Vent. (w/preheat)

3

8 
Table 11. Minimum Annual Heating Requirements in (million Btu) for CostEffective Modifications: 011 Furnace

Price Per Gallon (Oil)

$\$ 0.80 \quad \$ 1.00 \quad \$ 1.20$

I. Sequential Analysis

A. $n_{S S}=72 \%$

Improved Heat Exchanger

Stack Damper

Direct Vent. (w/preheat)

Improved Blower Eff. (@ $\$ .04 / \mathrm{kWh}$ )

$\begin{array}{rrr}3 & 3 & 2 \\ 14 & 11 & 10 \\ 50 & 40 & 35 \\ 25 & \mathrm{a} & \mathrm{b}\end{array}$

B. $\eta_{\text {ss }}=83 \%$

Improved Heat Exchanger

Stack Damper

Direct Vent. (w/preheat)

Improved Blower Eff. (@ $\$ .04 / \mathrm{kWh}$ )

$\begin{array}{ccc}3 & 3 & 2 \\ 15 & 12 & 11 \\ 70 & 53 & 44 \\ 12 & \mathrm{a} & \mathrm{b}\end{array}$

II. Independent Analysis

A. $n_{S S}=72 \%$

Improved Heat Exchanger

Stack Damper

Direct Vent. (w/preheat)

Improved Blower Eff. (@ $\$ .04 / \mathrm{kWh}$ )

$\begin{array}{rrr}3 & 3 & 2 \\ 16 & 13 & 11 \\ 14 & 11 & 10 \\ 60 & \mathrm{~b} & \mathrm{~b}\end{array}$

B. $\eta_{\mathrm{SS}}=83 \%$

Improved Heat Exchanger

Stack Damper

Direct Vent. (w/preheat)

Improved Blower Eff. (@ $\$ .04 / \mathrm{kWh}$ )

$\begin{array}{rrr}3 & 3 & 2 \\ 13 & 11 & 9 \\ 18 & 15 & 12 \\ 20 & \mathrm{a} & \mathrm{b}\end{array}$

III. Modified Sequential Analysis (No Stack Damper)

A. $n_{s s}=72 \%$

Improved Heat Exchanger

Direct Vent. (w/preheat)

Improved Blower Eff. (@ $\$ .04 / \mathrm{kWh}$ )

3
13
1

2

11

B. $\eta_{\text {sS }}=83 \%$

Improved Heat Exchanger

Direct Vent. (w/preheat)

Improved Blower Eff. (@ $\$ .04 / \mathrm{kWh}$ )

3
20
12

3
16

12

16

a

2

14

b

a Dolla /ings from improved blower efficiency ( $45 \%$ to $65 \%$ ) are positive but not large enough to offset higher blower motor cost.

b Iolla? sávings from improved blower efficiency ( $45 \%$ to $65 \%$ ) are negative. 
the improved blower motor modification is analyzed last for oil furnaces because of its general failure to be cost effective at oil prices of $\$ 1.00$ or more.* In both the sequential and the independent analysis the IID is assumed to be installed before any other modification is considered.

Except for the savings due to the IID and blower efficiency improvements, life-cycle savings for the modifications examined are almost directly proportional to the AHR. Thus, at an AHR twice those shown in tables 10 or 11 , life-cycle savings due to those remaining modifications are double costs. Efficiency improvements to the blower produce no actual reduction in Btu consumed at the building site, but rather require a substitution of fossil fuel for electrical energy so that total furnace output will remain constant. As a result, dollar energy savings, if any, tend to increase less than proportionally with increases in AHR. Moreover, if life-cycle fossil-fuel costs exceed life-cycle electricity costs when adjusted to the equivalent Btu output, the savings from improved blower efficiency will be negative. Such losses occur in table 11 when oil prices equal or exceed $\$ 1.00 /$ gallon, electricity prices equal $\$ 0.04 / \mathrm{kWh}$, and the seasonal furnace efficiency equals or is less than 77 percent.

In general, the improved blower efficiency modification (i.e., substitution of a permanent-split capacitor for a shaded pole motor) is cost effective for gas furnaces when annual heating requirements exceed aproximately five million Btu per year and the price of gas is approximately $\$ 0.30$ per therm. Since five million Btu per year is quite low for any house having central forced-air heating, this implies that a higher efficiency motor is likely to be cost effective in all installations. However, for oil furnaces the improved blower efficiency modification is not likely to be cost effective unless electricity prices are substantially greater than $\$ 0.04$ per $\mathrm{kWh}$.

The remaining modifications (improved heat exchanger, stack damper, and direct ventilation air with preheat) tend to be slightly more cost effective for the lower steady-state efficiency units than the higher steady-state efficiency units. For gas furnaces, these three modifications are all likely to be cost effective when AHR exceed $33 \mathrm{million}$ Btu at $\$ 0.30$ per therm. In oil furnaces, these same modifications are all likely to be cost effective when AHR exceeds 53 million Btu at $\$ 1.00$ per gallon. Using figure 1 as a reference for estimating the magnitude of AHR in a 1200 sq. ft. house, it can

* At $\$ 1.00 /$ gallon, UPW* $=18.5$ for oil, the present-value 20 -year cost per million Btu output =

$$
\frac{1,000,000 \mathrm{Btu}}{(140,000 \mathrm{Btu} / \text { gallon })(.77)}(\$ 1.00)(18.5)=\$ 172
$$

At $\$ 0.04 / \mathrm{kWh}$, UPW $=14.6$ for electricity, the present-value 20 -year cost per million Btu output $=$

$$
\frac{1,000,000 \mathrm{Btu}}{(3413 \mathrm{Btu} / \mathrm{kWh})(1.0)}(\$ 0.04)(14.6)=\$ 171 \text {. }
$$


be seen that the improved heat exchanger is likely to be cost effective' in all installations. However, the stack damper and direct ventilation with preheated air modifications are not likely to be cost effective in smaller houses or tightly insulated houses in the milder climates in the United States. Energy and dollar savings attributable to gas- and oil-fired boilers are assumed to be nearly identical to those calculated for the gas-and oil-fired furnaces.

\subsubsection{Implications for Outdoor Furnaces and Boilers}

The previous subsections have dealt with an economic evaluation of the cost effectiveness of various design options for furnaces (and boilers) intended for indoor installation. Another category of central heating equipment which needs to be considered is that of units intended for installation out-of-doors or in unheated spaces. This category includes gas-or oil-fired outdoor boilers, outdoor furnaces and horizontal furnaces.

Unlike indoor boilers and furnaces, the DoE test procedure requires that the seasonal performance of outdoor units be reduced by their estimated jacket losses at an average winter outdoor (attic or crawl space) temperature of $42^{\circ} \mathrm{F}$. The procedure employed tends to assign boilers a slightly larger jacket loss than furnaces* due to their generally higher mass and longer off-times and tends to show horizontal and outdoor furnaces as having slightly less efficient heat exchangers than their indoor, upflow and downflow conterparts.** Consequently, outdoor boilers and furnaces (including horizontal furnaces) both tend to have seasonal efficiencies which average between three and five percentage points below comparably equipped indoor units having the same steady-state efficiencies. As a result, the IID and improved heat exchanger design options which were shown previously to be cost effective for most indoor units are even more cost effective for outdoor boilers and furnaces. Stack dampers and preheated combustion air modifications, on the other hand, are not applicable to outdoor units because these units either do not employ draft diverters, draft hoods or barometric draft regulators*** or do employ these devices but use unheated outdoor air for draft control. The installation of a stack damper would serve no useful function on the latter type

* The jacket loss coefficient $\left(\mathrm{C}_{3}\right)$ assigned in the DoE test procedure is 4.7 for bollers and 3.3 for furnaces.

** This is believed to be due to a slightly higher mass per Btu/h input and a lower height to depth ratio.

*** The DoE test procedure defines a stack damper as an automatic damper "installed downstream of the intesral draft diverter, draft load or baromatic draft regulator." The application of a flue damper, which is an automatic damper installed upstream of the draft control device or vent terminal (on units not equipped with a draft control device), is not considered in this report because it is uncertain whether such devices save energy when installed on outdoor units and because the various associations concerned with safety have not yet approved the use of such devices on outdoor furnaces and boilers. 
units since heated air passing through the heat exchanger during the offperiod would simply exit through the draft relief opening and be lost.

\section{IMPLICATIONS FOR STANDARDS DEVELOPMENT}

\subsection{AN ECONOMICALLY OPTIMAL STANDARD FOR CONSUMERS}

The analysis conducted for this report suggests that a standard which requires the same level of fuel-utilization efficiency for all furnaces and boilers of a given type in the United States would not be the most costeffective standard possible. This is because some modifications to furnaces and boilers, particularly the stack damper and direct venting with preheated combustion air, were found to be cost effective only in installations with substantial annual heating requirements, not typical of smaller houses or tightly insulated houses in the milder regions of the U.S. As a result, if these two modifications are required in all new furnaces, consumers in such houses will not recoup the increased cost of the modifications. On the other hand, if these two modifications are not required, they will not be installed in many houses where they are clearly cost effective on a life-cycle cost basis.*

A standard which requires that a furnace or boiler achieve a given minimum level of efficiency can be made more cost effective if it requires higher efficiency levels only where those higher levels can be achieved at a cost less than or equal to the life-cycle savings in energy costs. Thus, a flexible standard could be developed which would link the performance requirements of a new furnace or boiler to the annual heating requirements of the building in which it is to be installed. Such a standard could be better implemented through the local building code authority than through equipment manufacturers.

It is unlikely that such a flexible standard will be adopted, however, because the legislation requiring minimum standards for central heating equipment imposes them on the manufacturer rather than the end user. Since the manufacturer has little control over the shipment of his units, this is tantamount to requiring the same minimum efficiency for all units produced. This, of course, is contrary to the principle of economic differentiation advocated above.

\subsection{A PRACTICAL STANDARD FOR MANUFACTURERS}

A compromise standard is possible, however, which retains some ability to differentiate among end uses while allowing the standard to be imposed on the manufacturer rather than the end user. Figure 2 shows a rough relationship between annual heating requirements and minimum design heating load,

* To the extent that such a problem can be attributed to a failure in consumer marketplace behavior, other mechanisms besides mandatory standards could be used to correct this situation. However, this is outside the scope of this report. 
based on figure 1. That is, for any given design heating load on the horizontal axis the corresponding AHR is likely to be at least as great as, if not greater than, that shown on the vertical axis. Using this relationship and an appropriate oversizing ratio, a minimum performance standard could be differentiated according to the output capacity of a furnace or boiler, rather than annual heating requirements. As a result larger furnaces or boilers would have higher efficiency requirements than smaller furnaces or boilers. By using energy prices which are representative of the region in which the modifications are likely to be marginally cost effective, this methodology will generally result in minimum standards which can be lifecycle justified in the majority of applications.

Table 12 provides a list of the design modifications examined in this report and the annul heating requirements needed to make them cost effective at the energy prices shown for gas- and oil-fired furnaces and boilers. The energy savings implicit in this table are based on the lower efficiency (i.e., 72 percent steady-state efficiency) units analyzed, since these units, modified as indicated, will likely serve as the base point for calculating minimum performance standards.* In addition, table 12 shows the corresponding design heating loads (based on figure 2) and output requirements (assuming an oversizing factor of 1.7 ). While this table is prescriptive in nature, minimum standards corresponding to these configurations could be formulated in performance terms, using seasonal fuel utilization efficiency as the performance measure. The seasonal fuel utilization efficiencies thus employed should be based upon experimental data obtained using the Department of Energy's furnace test procedure [5].

\subsection{OTHER CONSIDERATIONS IN SETTING STANDARDS FOR FURNACES AND BOILERS}

Design modifications required (either implicitly or explicitly) in setting a minimum efficiency standard must, in addition to being cost effective, meet other criteria outlined in section 2. One of these criteria is that the standard does not cause a major disruption of the industry. A design option which may not meet this requirement is direct venting with preheating of incoming combustion air on indoor furnaces and boilers. Even though Booz, Allen and Hamilton [1] gave the price of this design option as only $\$ 85$, its implementation requires a major redesign of a furnace or boiler. While a manufacturer might be willing to do this on a number of models in his manufacturing line, it is not reasonable to expect him to redesign all of his units unless a reasonably long lead time is given. Since it has been shown that direct venting with preheating is the least cost-effective design option examined, it is important that the number chosen for the furnace or boiler minimum performance standard not be set so high as to require this major design modification for all new residential, indoor, central heating equipment in the near future.

1. section 3.2, an efficiency of 72 percent was selected to bracket, on the low side, the steady-state efficiency of both gas and oil furnaces , 7 ? hoilers. 
Table 12. Furnace/Boller Output Capacities Corresponding to Annual Heating Requirements ${ }^{a}$

\begin{tabular}{ccc} 
Annual & Design & Furnace/ \\
Heating & Heating & Boller \\
Requilrements & Load & Output \\
$\left(10^{6}\right.$ Btu $)$ & $\left(10^{3}\right.$ Btu $)$ & $\left(10^{3}\right.$ Btu $)$ \\
\hline
\end{tabular}

I. Gas Furnace/Boiler

Modifications:

$\begin{array}{lrll}\text { (1) Improved Heat Exchanger } & 6 & 17 & 29 \\ \text { (2) Stack Damper } & 10 & 23 & 39 \\ \text { (3) Direct Vent. (w/preheat) } & 30 & 40 & 68\end{array}$

II. Oil Furnace/Boiler

(1) Improved Heat Exchanger $3013 \quad 22$

(2) Stack Damper $\quad 11 \quad 24 \quad 41$

(3) Direct Vent. (w/preheat) $40 \quad 45 \quad 77$

a For a given furnace or boller output that is properly sized, the annual heating requirements are 11 kely to be at least as great as shown, based on curve shown in figure 2. Based on sequential analysis of modifications, with IID used in all cases.

b From tables 10 and 11 for the $72 \%$ steady-state efficiency units.

c Output = design heating load $\times 1.7$ (oversizing factor). 
A second criterion which must be met by a minimum standard is that it does not force unsafe, unreliable, and unacceptable products on the consumer. A design option which may give unacceptable performance is the installation of stack dampers on indoor oil-fired furnaces and boilers. A recent study involving the installation of stack dampers on 23 existing oil-fired furnaces and boilers in the New England area [8] resulted in odor problems in 11 installations and eventual disconnection of eight (35 percent) of the devices for this reason. Although this was a retrofit study, the burners, furnaces and boilers were representative of those presently being manufactured and there is no reason to believe that this problem could not also exist for new equipment. Based upon this uncertainty, it is recommended that for the present time minimum performance standards for oil-fueled furnaces and boilers be set at a level which does not require manufacturers to install stack dampers on oil-fired equipment. The normal incentives of high fuel costs and appliance labeling as well as the performance nature of the standards should encourage manufacturers to incorporate this design option on many of their indoor units as the odor problem is solved. If this occurs without significant problems, minimum standards for oil-fired furnaces and boilers could then be raised to reflect the use of stack dampers on this type of equipment."

A third criterion is that all minimum standards must be based upon results obtained using DoE test procedures [5]. However, the use of improved blower motors on gas furnaces cannot be factored into a minimum efficiency standard for furnaces based on these procedures. While the electrical energy consumed (and the heat given off) by a furnace blower is used in the test procedure to determine the annual operating cost, it does not enter into the calculation of the seasonal efficiency number. This was done to prevent manufacturers from trading off increased operating costs (and total resource energy consumption) for a higher seasonal efficiency number. This situation could best be corrected by DoE modifying its present definition of seasonal efficiency from one based upon onsite fuel consumption to one based upon resource energy requirements (sometimes referred to as "energy at the coal pile") or to one based on cost weighting factors for the different energy types used. If this is not possible, an alternative solution is proposed in section 6 which could achleve many of the same benefits.

Evaluating the life-cycle cost study results summarized in section 4.5 .1 , in light of these three criteria, leads to the conclusion that only the following design modifications should be considered in setting minimum performance standards:

1) an IID on both indoor and outdoor gas-fired units (oil-fired units already incorporate this desibn option),

It should be noted that the direct venting (with preheat) option is likely to be cost effective on all oil furnace and boiler systems if the stack damper is not used. However, the major design changes required for this modification weigh against its immediate incorporation into the proposed minimum standard. 
2) an improved heat exchanger on all indoor and outdoor furnaces and bollers (corresponding to five percentage points increase in steadystate efficiency), and

3) the use of stack dampers on indoor gas-fired furnaces and bollers with output capacities equal to or greater than $40,000 \mathrm{Btu} / \mathrm{h}$.

Manufacturers would, of course, be free to achieve this minimum level of performance by whatever means possible (such as by using power burners, direct venting with preheating of incoming combustion air, etc.).

\subsection{TECHNICAL BASIS FOR STANDARDS SETTING}

\subsubsection{Gas Furnaces and Boilers}

An analysis of data presented by the Gas Appliance Manufacturers Association (GAMA) [7] reveals that, with the exception of one gas furnace, the lowest steady-state efficiencies measured by GAMA for current production models of gas furnaces and bollers was approximately 72 percent. A five percentage point improvement in the steady-state efficiency, due to an improved heat exchanger, would increase this steady-state efficiency to 77 percent. An NBS technical analysis of gas furnaces [11], based on the DoE furnace test procedure and thought currently to be the most reliable summary of results obtalned using this procedure, shows that a steady-state efficiency of 77 percent corresponds to an expected seasonal efficiency of 68 percent for gasfired furnaces and boilers equipped with IID's and an expected seasonal efficiency of 74 percent for gas-fired indoor furnaces and boilers equipped with both IID's and stack dampers.

Relating seasonal efficlency and steady-state efflciency for gas-fired outdoor units is considerably more difficult because of the limited amount of data available on these systems. The best approach appears to be to adjust the average seasonal efficiency of 68 percent, found for indoor units equipped with an IID and having a steady-state efficiency of 77 percent, for the effect of jacket losses and for the reduced heat exchanger effectiveness of outdoor (including horizonta1) furnaces. Assuming a typical jacket loss of 0.75 percent on a well insulated furnace or boiler tested in the laboratory, the seasonal jacket loss (as calculated in the DoE furnace test procedure) becomes $(0.75 \times 3.3 \Rightarrow 2.5$ percent for outdoor furnaces and $(0.75 \times 4.7=)$ 3.5 percent for outdoor boilers. If a value of 2.0 percentage points is assigned to account for reduced heat exchanger performance, * it is concluded that an outdoor furnace with a steady-state efficlency of 77 percent is likely to have a seasonal efficiency of approximately (68-2.5-2=) 63.5 percent. Subtracting the seasonal jacket loss for outdoor boilers from 68

* This is perhaps the weakest point in the argument. It is based upon the test of a single unit at NBS and data contained in a draft report by AGA laboratories [6]. It is suggested that when DoE proposes minimum standards they also request manufacturers to provide actual test data on horizontal units tested arcording to the $\mathrm{DoE}$ test procedure. 
percent yields a seasonal efficiency of approximately 64.5 percent. Within the accuracy of this analysis, it would appear that a seasonal efficiency of approximately 64 percent might reasonably be expected from both outdoor furnaces and boilers having a steady state efficiency of about 77 percent and employing an intermittent ignition device (IID).

Based upon these results and the fact that minimum standards give the lowest levels of acceptable performance, the following minimum performance standards for gas-fired, residential, central heating equipment appear to be generally cost effective and compatable with the criteria for standards development detailed in section 2 .

Table 13. Minimum Seasonal Efficiencies for Gas-Fired Central Heating Equipment

Type of Heating Equiprent

Minimum Seasonal Efficiency As Measured Using the DoE Furnace Test Procedure [5]

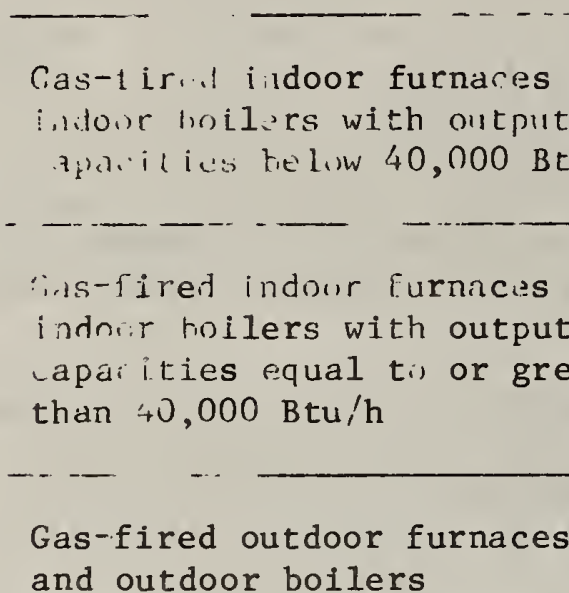

and outdoor boilers

The above minimum standards for gas-fired units should assure that most of the gas-fired indoor units presently being manufactured would be required to have a seasonal efficiency at least as high as a low efficiency furnace/ boiler equipped with an IID, an improved heat exchanger and a loose stack damper. In addition, the development and production of small capacity indoor units would not be hindered by forcing them to be equipped with a design option (e.g. stack damper) which may not generally be cost effective.

\subsubsection{O11 Furnaces and Boilers}

The lowest steady-state efficiency reported for oil-fired furnaces and boilers by GAMA is approximately 75 percent [7]. A five percentage point increase in this steady-state efficiency due to an improved heat exchanger would result in a steady-state efficiency of 80 percent. 
NBS technical analysis of furnaces [11], based on the DoE test procedure, shows that a steady-state efficiency of 80 percent corresponds to an expected seasonal efficiency of approximately 76 percent for the oil-fired indoor furnaces and boilers tested. For oil-fired outdoor units, the same type of analysis that was carried out for gas-fired outdoor units yields a seasonal efficiency of approximately 73 percent if a typical laboratory measured jacket loss of 0.75 percent is assumed and the effect of reduced heat exchanger effectiveness on outdoor furnaces is taken to be one be one percentage point.*

Based upon these results, the following minimum performance standards for oilfired residential heating equipment are generally cost effective and consistent with the criteria for standards development outlined in section 2 .

Table 14. Minimum Seasonal Efficiencies for Oil-Fired Central Heating Equipment

Type of Heating Equipment

Minimum Seasonal Efficiency As Measured Using the DoE Furnace Test Procedure [5]

Al1 oil-fired indoor furnaces and indoor boilers

All oil-fired outdoor furnaces and outdoor boilers

It is recommended that this minimum seasonal efficiency number be revised upward to 80 percent** for ofl-fired indoor furnaces and boilers with output capacities equal to or greater than $40,000 \mathrm{Btu} / \mathrm{h}$, if at a later date it is determined that the addition of stack dampers to this type of indoor equipment does not cause insurmountable odor problems.

Finally, it is recommended that any minimum efficiency numbers adopted by the Department of Energy be periodically subjected to review and that they be revised as energy costs, modification costs, product lines and installation practices change.

* A value of one percentage point was used instead of two percentage points, because the difference between the steady-state and seasonal efficiencies shown for oil-fired units are approximately half that shown for gas-fired units.

** This gives a seasonal efficiency equal to the steady-state efficiency. To require a higher seasonal efficiency as a result of installing a stack damper could be unfair to oil-fired furnaces and boilers with lightweight heat exchangers. 


\section{AN ALTERNATIVE METHOD FOR SPECIFYING MINIMUM BLOWER MOTOR EFFICIENCY}

It was mentioned previously that while the use of high efficiency blower motors on gas furnaces was justifled economically, this design option could not be used in setting minimum efficiency standards for furnaces because the DoE seasonal efficiency calculation did not account for the auxiliary electrical energy consumed by fossil-fuel-fired central heating equipment. One alternative which would allow both the consumer and the country to benefit from the resource energy saved by using more efficient blower motors is for DoE to change its definition of furnace annual efficiency to account for the electrical energy used. A second alternative would be, for each category of furnace, to have two minimum efficiency standards: one based on the data base developed in section 5 for the annual fuel utilization efficiency and a second specifying the minimum allowable blower motor efficiency. In the event that DoE wishes to avail itself of the latter alternative, the following efficiency data for consideration in the development of minimum performance standards for furnace blower motors has been provided:

Table 15. Minimum Efficiencles for Furnace Blower Motors

Motor size (HP)
$1 / 7<\mathrm{HP}<1 / 5$
$50 \%$
$1 / 5<\mathrm{HP}<1 / 3$
$55 \%$
$\mathrm{HP} \geq 1 / 3$
$60 \%$

These are based on the data shown in figure 3 for the typical spread currently found in the efficiency of permanent-split capacitor (P.S.C.) and shaded pole (S.P.) motors. The data was supplied by a leading manufacturer of furnace blower motors. The solid step-like line in figure 3, which represents the above referenced minimum efficlencies for furnace blower motors, would force manufacturers to switch from S.P. motors to more efficient and more costeffective P.S.C. motors.

Blower motor efficiencies should be measured in accordance with IEEE Standard 114 (Test Procedure for Single-Phase Induction Motors) with the motor operating at full load or at the high speed connections. This information should be readily available from the blower motor manufacturer and no testing or verification of motor performance should be required of the furnace manufacturer.

\section{CONCLUSIONS}

The National Energy Act of 1978 requires that the Department of Energy (DoE) develop minimum performance standards for new residential gas- and oil-fired furnaces and bollers produced in the U.S. This report examines available 


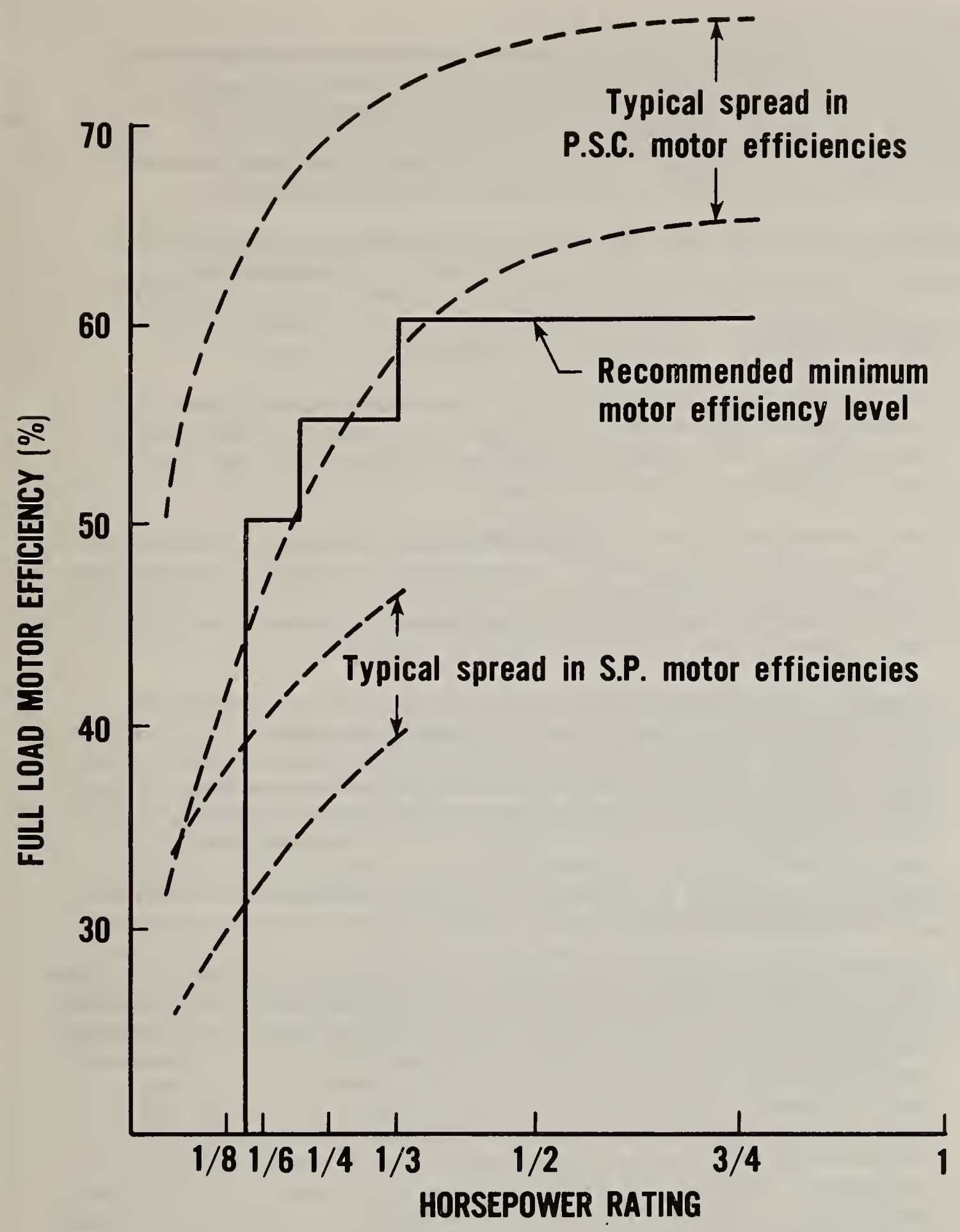

Figure 3. Typical P.S.C. and S.P. motor efficiencies and suggested minimum motor efficiency level (data on typical motor efficiencies supplied by a leading manufacturer of furnace blower motors) 
technological improvements to such systems in order to determine which are likely to be cost effective from a consumer standpoint and implementable without serious disruption to the industry. Performance data, in terms of seasonal conversion efficiencies, are then identified which correspond to basic furnace and boiler systems incorporating those improvements. These specifications can be used as the basis of minimum performance standards that are life-cycle-cost justified in the majority of applications.

The following conclusions are specifically forthcoming from this report:

(1) The intermittent ignition device for a gas furnace is likely to be cost effective in all installations when compared to the annual cost of a standing pilot light.

(2) An improved heat exchanger (five percentage points above the steady-state efficiency of the base case models identified in this report) will likely be cost effective in all gas - and oil-fired central heating equipment.

(3) The cost-effectiveness of a stack damper is largely related to the magnitude of the annual heating requirements of the building in which the furnace/boiler is installed. In houses with relatively small annul heating requirements, the stack damper is not currently cost effective in many cases.

However, for larger houses and houses in colder climates the stack damper is generally cost effective on a life-cycle basis. As a result, stack dampers are found to be generally cost effective for indoor gas furnaces and boilers with output capacities above $40,000 \mathrm{Btu} / \mathrm{h}$. Odor problems associated with stack dampers in oil furnaces and boilers suggest that this modification is not presently suited for general use in these latter systems until this problem is eliminated. Stack dampers do not appear to reduce energy usage significantly when used in outdoor units.

(4) Direct outdoor venting with preheated air appears to be life-cycle cost effective primarily in houses with relatively large heating requirements, making this design modification practical for most indoor gas furnaces and boilers with output capacities above approximately $68,000 \mathrm{Btu} / \mathrm{h}$ and for most indoor oil furnaces and boilers above $77,000 \mathrm{Btu} / \mathrm{h}$ if a stack damper is used as well. If a stack damper is not used, the external ventilation with preheated air will also be cost effective on somewhat smaller equipment. However, if direct venting with preheated air is made mandatory, a major disruptio. of the industry is likely to result, since major design changes would be required of virtually all new furnaces and boilers. As a result, this modification is not suggested as a feature to be implicitly included in the performance standard. Because of the nature of the performance standard, however, manufacturers can take credit for incorporating this feature into new furnace designs as new equipment lines are produced. 
(5) Improved heat exchangers and intermittent ignition devices appear to be cost-effective modifications to furnaces and boilers installed outside of the conditioned space. However, the stack damper and preheated ventilation air modifications do not add significantly to the seasonal efficiency of these units and thus are not likely to be cost effective.

(6) Minimum performance levels for gas and oil furnaces and boilers corresponding to the above analysis can be stated as follows:

\section{Furnace/Boiler Type}

Seasonal Efficiency

A. Indoor Units

1. Units with less than $40,000 \mathrm{Btu} / \mathrm{h}$ output

$68 \%$

$76 \%$

2. Units with $40,000 \mathrm{Btu} / \mathrm{h}$ output or greater

B. Outdoor Units (all)

(7) While some improvement in the efficiency of the blower motor for furnaces appears to be quite cost effective for gas furnaces, this improvement cannot be directly factored into a performance standard based on the DoE test method. Thus a separate performance standard for blower motor efficiency may be advisable.

In addition to these conclusions, it should be recognized that much of the performance data utilized in this report is based on either limited testing or simulated results. Additional measured data on performance improvements related to design modifications would be of considerable help both in improving the standards development process and in determining the extent to which the modifications examined will enable the manufacturer to most economically comply with the standards as they are promulgated. 


\section{REFERENCES}

1. Booz, Allen and Hamilton, Inc., Energy Efficiency Program for Appliances: Furnaces, Home Heating Equipment, Humidifiers, Volume II, October 1977.

2. Bureau of Labor Statistics, "Consumer Prices: Energy", USDL-80-111, Washington, D.C., January 1980.

3. Chi, J., Kelly, G. and Didion, D., "Use of a Computer Model to Evaluate Energy Savings Potentials for Gas-Fired Furnaces," Paper \#78-IHTC-77 given at 1978 International Heat Transfer Conference, Toronto.

4. Department of Energy, "Energy Conservation Program for Consumer Products," Federal Register, Vol. 44, No. 1, January 2, 1979.

5. Department of Energy, "Test Procedures for Furnaces and Vented Home Heating Equipment," Federal Register, Vo1. 43, No. 91, Wednesday, May 10, 1978, pages 20108 through 20205 .

6. DeWerth, D. W., "Evaluation of the Proposed DoE Efficiency Rating Procedures for Furnaces," Draft report sponsored by the Gas Appliance Manufacturers Association and the American Gas Association Laboratories, January 1978 .

7. Gas Appliance Manufacturers Association (GAMA), memo to Efficiency Task Group of the Furnace and Boiler Division, November 23, 1977 (unpublished).

8. Katzman, L., Kelly, George E. and Kuklewicz, Mark E., "An Assessment of Retrofitting Automatic Vent Dampers on Oil-Fired Residential Heating Systems in the New England Area," 1978 HVAC Equipment and Systems Conference, Purdue University, October 23-25, 1978.

9. Kelly, G., Chi, J. and Kuklewicz, M., Recommended Testing and Calculation Procedures for Determining the Seasonal Performance of Residential Central Furnaces and Boilers, NBSIR 78-1543, National Bureau of Standards, March 1978.

10. National Bureau of Standards, "Appliance Energy Efficiency Improvement Target - Furnaces," Letter Report to Department of Energy, September 1, 1977.

11. National Bureau of Standards, "Technical Analyses of Public Hearing Testimony Regarding Proposed Energy Efficiency Improvement Targets for Furnaces," Letter Report to Department of Energy, March 23, 1978.

12. Petersen, Stephen R., Economics and Energy Conservation in the Design of New Single-Family Housing, NBS Building Science Series, in review.

13. Sitzer, Moden and DonVito, Historical and Forecasted Energy Prices by DoE Region and Fuel Type for Three Macroeconomic Scenarios, DoE/EIA$0184 / 15$, Department of Energy, Washington, D.C., 1979.

14. Stamper, E., "Weather Data," ASHRAE Journal, February 1977, p. 47. 


\section{APPENDIX A \\ DERIVATION OF MODIFIED UNIFORM PRESENT WORTH FACTORS}

One of the most critical aspects of a life-cycle cost analysis is that of evaluating a flow of future benefits or costs associated with some design change in present-value terms. In general, this requires that future benefits or costs be discounted to present value using an appropriate discount rate. The purpose of this appendix is to show the derivation of the modified ${ }^{*}$ uniform present worth (UPW*) factors used to evaluate the present value of the energy savings over the life of the modifications examined.

Dollar-valued energy savings can be calculated for each year over the life of a design modification and discounted to present value. However, if the physical energy savings are assumed constant from year to year, it is generally easier to calculate a modified uniform present worth factor which, when multiplied by the annual energy savings calculated at the cost of energy in the initial time period, will produce the same results.

That is:

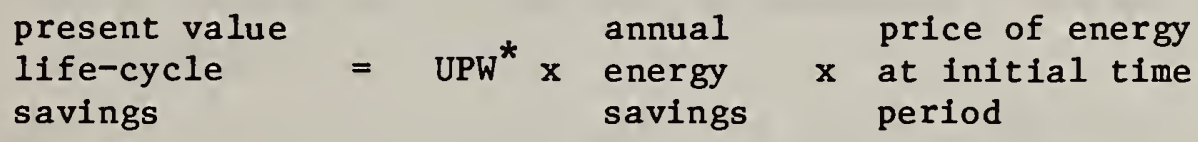

The UPW* factor is a function of the life over which the savings are expected to be realized, the discount rate, and the rate at which energy prices are expected to increase over the life of the modification. A 20year life and a four percent real discount rate (1.e. four percent above the rate of inflation) are assumed in this report, as discussed in section 4.4.2. The rate of energy price increase for each type of energy examined (gas, oil, and electricity) is derived from the DoE energy price projections [12].

If the discount rate and the rate of energy price escalation are constant over the life of the modifications, the modified uniform present worth factor can be calculated using:

$$
U P W^{*}=\sum_{t=1}^{L}\left(\frac{1+P}{1+D}\right)^{t}
$$

* The term "modified" is used to describe a uniform present worth factor which incorporates an increasing cash flow over time rather than a conventional UPW factor which is based on a constant cash flow over time. 
where

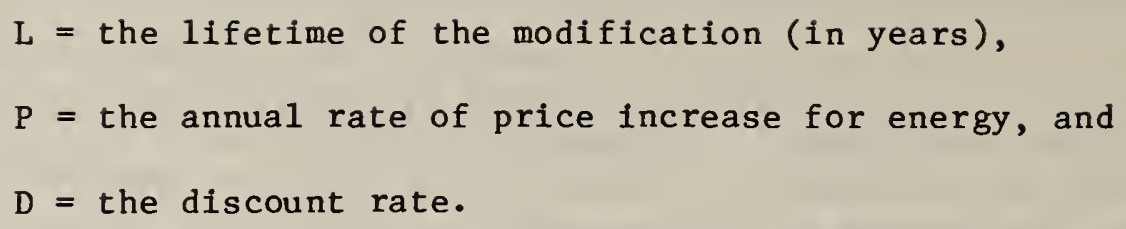

Note that if $P=D$, the increase in fuel prices just offsets the discount rate so that the $\mathrm{UPW}^{*}$ is equal to the lifetime in years, i.e., the savings are simply added each year at initial year energy prices.

If $P$ does not equal $D$, equation $A-1$ can be reformulated as:

$$
\mathrm{UPW}^{*}=\left(\frac{1+\mathrm{P}}{\mathrm{D}-\mathrm{P}}\right)\left(1-\left(\frac{1+\mathrm{P}}{1+\mathrm{D}}\right)^{\mathrm{L}}\right) \text {. }
$$

Based on the real rates of fuel and electricity price increase derived in section 4.2 .2 , a four percent real discount rate and a 20-year equipment life, the UPW ${ }^{*}$ factors used in the report were calculated as follows:

$$
\begin{aligned}
& \text { Gas: } \quad P=3.4 \% \\
& \text { UPW }^{*}=\left(\frac{1.034}{0.006}\right)\left(1-\left(\frac{1.034}{1.04}\right)^{20}\right)=18.8 \\
& \text { Oil: } \quad P=3.2 \% \\
& \text { UPW }^{*}=\left(\frac{1.032}{0.006}\right)\left(1-\left(\frac{1.032}{1.04}\right)^{20}\right)=18.5 \\
& \text { Electricity: } \quad P=0.8 \% \\
& \text { UPW }^{*}=\left(\frac{1.008}{0.032}\right)\left(1-\left(\frac{1.008}{1.04}\right)^{20}\right)=14.6
\end{aligned}
$$




\section{APPENDIX B}

\section{EXPLANATION OF DESIGN MODIFICATIONS TO FURNACES/BOILERS*}

\section{Power Burner (or Induced Draft or Forced Draft)}

The installation of a fan for supplying combustion air or for force venting the products of combustion tends to reduce the off-period losses and, thus, improve a unit's seasonal efficiency. The fan can be installed ahead of the combustion chamber (forced draft) or after the combustion chamber (induced draft.)

Fuel and Air Modulation

The magnitude of off-cycle losses can be reduced by increasing system ontime and reducing the rate of fuel input to the furnace or boiler. However, a simultaneous reduction in combustion air provided to the burner to avoid large excess air ratios must accompany the reduction in fuel input in order to avoid adverse affects on system efficiency. Fuel input can be modulated in discrete steps or continuously, but is limited at the lower end due to considerations for condensation and flame stability.

Automatic Stack Damper (Vent Damper)

The presence of a vent system and chimney on a conventional furnace significantly reduces the seasonal efficiency of these appliances. Immediately after the termination of combustion, the heat stored in the heat exchanger provides a driving force which causes a flow of air through the exchanger and up the chimney. This flow carries with it whatever heat remains in the exchanger after the circulating air blower is switched off. In addition to causing heat exchanger cool down, the exfiltrated air (including air passing through the draft control devices) must be made up by increased infiltration of cold air into the house. The installation of an automatic damper in the vent pipe, downstream of the draft diverter or draft regulator, can significantly reduce the volume of this flow.

Intermittent Ignition Device (Electric Pilot)

Ignition of the main burner in a gas-fired heating system has traditionally been accomplished by using a standing, or continuously burning, pilot light. During the non-heating season, the fuel consumed by the pilot is wasted. This loss reduces the annual efficiency of the appliance. Replacement of the standing pilot with an intermittent ignition device has the potential, therefore, of decreasing energy consumption. The IID ignites by spark ignition either the main burner directly or a pilot flame.

* Based on Booz, Allen and Hamilton, Inc., "Energy Efficiency Program for Appliances, Furnaces, Home Heating Equipment, Humidifiers [1]. 
A standard furnace, installed in an indoor location, uses conditioned air for both combustion and draft control. This air, which is exfiltrated from the house through the chimney, increases the amount of cold air infiltrated into the house from the outside. The necessity of having to heat this air to indoor conditions results in a loss of efficiency for the system. The loss can be eliminated by sealing the combustion chamber from the area in which it is installed and bringing combustion air in from the outside through a suitably designed vent. In order to improve the seasonal efficiency of the appliance, the vent/air intake system should be designed to use the existing hot flue gas to preheat the incoming combustion air.

\section{Improved Heat Exchanger}

The steady-state efficiency of conventional furnaces is governed primarily by the effectiveness of the heat exchanger. A 5 percentage point increase in steady-state efficiency, up to 80-82 percent, can be achieved by increasing the size of the heat exchanger with respect to the burner firing rate, or by reducing the firing rate and keeping the heat exchanger size and the excess air ratio constant.

\section{High Efficiency Blower Motor}

The upgrading of blower motor type from the conventional shaded pole motor used in most furnaces in the mid 1970's to a permanent-split capacitor type motor would represent approximately 30 percent less consumption of electricity. The permanent-split capacitor motor with its extra windings and running capacitor achieves the same horsepower while consuming less electricity. 


\begin{tabular}{|c|c|c|}
\hline $\begin{array}{l}\text { U.S. DEPT. OF COMM. } \\
\text { BIBLIOGRAPHIC DATA } \\
\text { SHEET }\end{array}$ & $\left.\begin{array}{l}\text { 1. PUBLICATION OR REPORT NO. } \\
\text { NBSIR } 80-2079\end{array}\right]$ 2. Covit: Aecession No. & 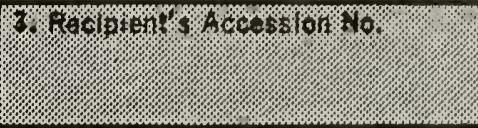 \\
\hline \multirow{2}{*}{\multicolumn{2}{|c|}{$\begin{array}{l}\text { 4. TITLE AND SUBTITLE } \\
\text { An Economic Analysis of Efficiency Improvements to } \\
\text { Residential Gas-and Oil-Fired Central Heating Equipment }\end{array}$}} & $\begin{array}{l}\text { 5. Publication Date } \\
\text { July } 1980\end{array}$ \\
\hline & & 6. Pertorming Organization Code \\
\hline \multicolumn{2}{|c|}{$\begin{array}{l}\text { 7. AUTHOR(S) } \\
\text { Stephen R. Petersen, George E. Kelly }\end{array}$} & 8. Performing Organ. Report No. \\
\hline \multirow{2}{*}{\multicolumn{2}{|c|}{ 9. PERFORMING ORGANIZATION NAME AND ADDRESS }} & $\begin{array}{l}\text { 10. Project/Task/Nork Unit No. } \\
742.2506\end{array}$ \\
\hline & & 11. Contract/Grant No. \\
\hline \multirow{2}{*}{\multicolumn{2}{|c|}{$\begin{array}{l}\text { 12. SPONSORING ORGANIZATION NAME AND COMPLETE ADDRESS (Streot, City, State, zIP) } \\
\text { Department of Energy } \\
20 \text { Massachusetts Ave., N.W. } \\
\text { Washington, D.C. } 20585\end{array}$}} & $\begin{array}{l}\text { 13. Type of Report \& Period Covered } \\
\text { Fina1 }\end{array}$ \\
\hline & & 14. Sponsoring Agency Code \\
\hline
\end{tabular}

15. SUPPLEMENTARY NOTES

[ Document describes a computer program; SF-185, FIPS Software Summary, is attached.

16. ABSTRACT (A 200-word or less factual summary of most sigrificant information. If document includes a significant bibliography or iterature survey, mention it here.)

Minimum performance standards for new residential gas- and oil-fired furnaces and boilers will be promulgated by the Department of Energy in the early 1980's. These standards will implicitly require that a number of design modifications be made to improve the seasonal efficiency of many basic furnace/boiler configurations. This report examines the potentialimprovement in seasonal efficiency due to a number of such modifications, as well as their life-cycle cost effectiveness. Included in the analysis are intermittent ignition devices (for gas-fired equipment), improved heat exchangers, stack dampers, external venting (with preheated air), and improved blower motor efficiencies (for forced-air furnaces). NBS DEPAF simulation data, the DOE/NBS furnace and boiler test procedures, current estimates of modification costs, and a wide range of annual heating requirements and fuel costs are used in the analysis. Minimum efficiency criteria for new furnaces and boilers are developed, based on the estimated performance of current configurations representative of lower efficiency models, upgraded with those energy-saving modifications which are generally cost effective and can be implemented without serious disruption in the industry.

17. KEY WORDS (six to twelve entries; alphabetical order; capitalize only the first letter of the first key word unless a proper name; separated by semicolons)

Boilers; central heating equipment; economic analysis; furnaces; incremental savings; life-cycle costs; minimum efficiency levels; minimum efficiency standards.

18. AVAILABILITY

[X] Unlimited

For Official Distribution. Do Hot Release to NTIS

Order From Sup. of Doc., U.S. Government Printing Office, Wasinington, DC 20402, SD Stock No. SNÓ03-003-

X] Order From National Technical Information Service (NTIS), Springfield, VA. 22161

\begin{tabular}{|l|c|}
\hline $\begin{array}{l}\text { 19. SECURITY CLASS } \\
\text { (THIS REPORT) }\end{array}$ & $\begin{array}{c}\text { 21. NO. OF } \\
\text { PRINTED PAGES } \\
\text { UNCLASSIFIED }\end{array}$ \\
\hline $\begin{array}{l}\text { 20. SECURITY CLASS } \\
\text { (THIS PAGE) }\end{array}$ & $\begin{array}{l}\text { 22. Price } \\
\text { UNCLASSIFIED }\end{array}$ \\
\hline
\end{tabular}




